Article

\title{
Must the Best Laboratory Prepared Catalyst Also Be the Best in an Operational Application?
}

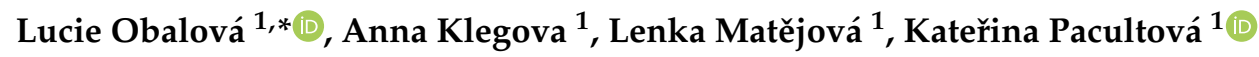 \\ and Dagmar Fridrichová 1,2 \\ 1 Institute of Environmental Technology, VŠB - Technical University of Ostrava, 17. listopadu 15/2172, \\ 70800 Ostrava, Czech Republic; anna.klegova@vsb.cz (A.K.); lenka.matejova@vsb.cz (L.M.); \\ katerina.pacultova@vsb.cz (K.P.); dagmar.fridrichova@vsb.cz (D.F.) \\ 2 Centre ENET, VŠB - Technical University of Ostrava, 17. listopadu 15/2172, 70800 Ostrava, Czech Republic \\ * Correspondence: lucie.obalova@vsb.cz
}

Received: 23 December 2018; Accepted: 30 January 2019; Published: 7 February 2019 updates

\begin{abstract}
Three cobalt mixed oxide deN $\mathrm{N}_{2} \mathrm{O}$ catalysts, with optimal content of alkali metals (K, Cs), were prepared on a large scale, shaped into tablets, and tested in a pilot plant reactor connected to the bypassed tail gas from the nitric production plant, downstream from the selective catalytic reduction of $\mathrm{NO}_{\mathrm{x}}$ by ammonia (SCR $\left.\mathrm{NO}_{x} / \mathrm{NH}_{3}\right)$ catalyst. High efficiency in $\mathrm{N}_{2} \mathrm{O}$ removal $\left(\mathrm{N}_{2} \mathrm{O}\right.$ conversion of $75-90 \%$ at $450{ }^{\circ} \mathrm{C}, \mathrm{VHSV}=11,000 \mathrm{~m}^{3} \mathrm{~m}_{\text {bed }}{ }^{-3} \mathrm{~h}^{-1}$ ) was achieved. However, a different activity order of the commercially prepared catalyst tablets compared to the laboratory prepared catalyst grains was observed. Catalytic experiments in the kinetic regime using laboratory and commercial prepared catalysts and characterization methods (XRD, TPR $-\mathrm{H}_{2}$, physisorption, and chemical analysis) were utilized to explain this phenomenon. Experimentally determined internal effectiveness factors and their general dependency on kinetic constants were evaluated to discuss the relationship between the catalyst activity in the kinetic regime and the internal diffusion limitation in catalyst tablets as well as their morphology. The theoretical $\mathrm{N}_{2} \mathrm{O}$ conversion as a function of the intrinsic kinetic constants and diffusion rate, expressed as effective diffusion coefficients, was evaluated to estimate the final catalyst performance on a large scale and to answer the question of the above article title.
\end{abstract}

Keywords: internal effectiveness factor; effective diffusion coefficient; $\mathrm{N}_{2} \mathrm{O}$; catalytic decomposition; cobalt mixed oxide; alkali metal; promoter

\section{Introduction}

Research of new catalysts for industrial application is a time-consuming and costly process. It is usually based on a large number of laboratory catalytic experiments, which provide feedback for the optimization of catalyst preparation procedure, its chemical and phase composition, morphology, dispersion, and a number of other physicochemical characteristics which are necessary to obtain the desired catalytic properties. The result of laboratory research is the recipe for preparation of the optimized catalyst on a larger scale (approx. $100 \mathrm{~kg}$ ), its production, and pilot plant testing.

In the presented work, based on previous extensive laboratory screening tests of $\mathrm{N}_{2} \mathrm{O}$ catalytic decomposition [1-3], three cobalt mixed oxide $\mathrm{deN}_{2} \mathrm{O}$ catalysts with optimal content of alkali metals $\mathrm{K} / \mathrm{Co}_{4} \mathrm{MnAlO}_{x}, \mathrm{Cs} / \mathrm{Co}_{4} \mathrm{MnAlO}_{\mathrm{x}}$, and $\mathrm{Cs} / \mathrm{Co}_{3} \mathrm{O}_{4}$ were prepared on a large scale, shaped into tablets and tested in the pilot plant reactor connected to the bypassed tail gas from the nitric production plant. Results of pilot plant testing of $\mathrm{K} / \mathrm{Co}_{4} \mathrm{MnAlO}_{x}$ for decreasing $\mathrm{N}_{2} \mathrm{O}$ emissions from a nitric acid plant were published in our previous work [4]. Although high efficiency in $\mathrm{N}_{2} \mathrm{O}$ removal $\left(\mathrm{N}_{2} \mathrm{O}\right.$ conversion of $75-90 \%$ at $450{ }^{\circ} \mathrm{C}$, VHSV $=11,000 \mathrm{~m}^{3} \mathrm{~m}_{\text {bed }}{ }^{-3} \mathrm{~h}^{-1}$ ) were reached; the question is if the prepared tablet catalyst achieved similar catalytic performance to the laboratory catalyst or if it was lower and 
in the latter case optimization of the pilot catalyst's preparation procedure would then be beneficial. The same question applies in the case of the remaining two catalysts. For Cs $/ \mathrm{Co}_{4} \mathrm{MnAlO}_{x}$, the results of pilot plant testing were published in [5] and for $\mathrm{Cs} / \mathrm{Co}_{3} \mathrm{O}_{4}$ catalyst, the pilot-testing results have not yet been published.

The aim of this paper is to answer the question already posed in the title. Catalytic experiments in kinetic regime using laboratory and commercial prepared catalysts and characterization methods (XRD, TPR- $\mathrm{H}_{2}$, physisorption and chemical analysis) were utilized to answer this question. The procedure for determination of (i) the effective diffusion coefficients from catalytic experiments and (ii) the theoretical limits of catalyst performance on a large scale is shown. The presented approach is generally valid and can be used also for other reactions of 1 st order kinetics.

\section{Results}

\section{1. $\mathrm{N}_{2} \mathrm{O}$ Catalytic Decomposition}

Figure 1 compares the laboratory and pilot-plant results of $\mathrm{N}_{2} \mathrm{O}$ catalytic decomposition. Laboratory experiments were performed using laboratory-prepared catalysts in the form of grains and the conversion of $\mathrm{N}_{2} \mathrm{O}$ was observed in a gaseous mixture simulating real waste gas conditions. Pilot-plant experiments were performed on commercially prepared tablets in real tail-gas from a nitric acid plant. High efficiencies in $\mathrm{N}_{2} \mathrm{O}$ removal in both laboratory and pilot-plant conditions were reached, comparable with the best results from the literature $[6,7]$.

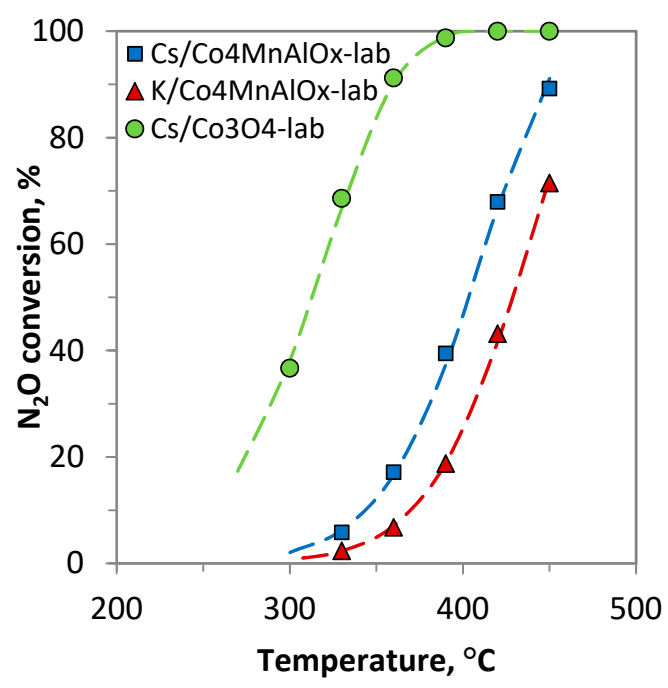

(a)

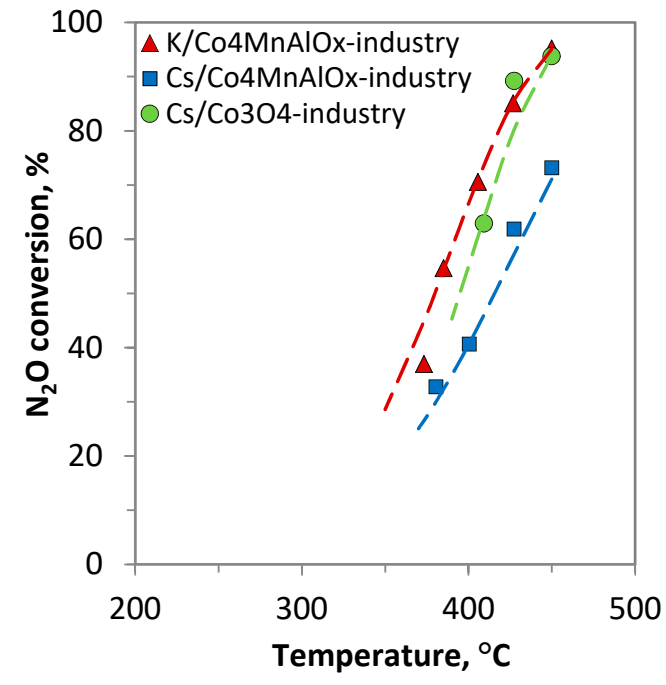

(b)

Figure 1. $\mathrm{N}_{2} \mathrm{O}$ catalytic decomposition over: (a) laboratory prepared catalyst grains in simulated process condition (1000 ppm $\mathrm{N}_{2} \mathrm{O}+5 \mathrm{~mol} \% \mathrm{O}_{2}+2 \mathrm{~mol} \% \mathrm{H}_{2} \mathrm{O}$ in $\mathrm{N}_{2}, \mathrm{GHSV}=60,000 \mathrm{l} \mathrm{kg}^{-1} \mathrm{~h}^{-1}$ ); (b) commercially prepared catalyst tablets in real waste gas (VHSV $=11,000 \mathrm{~m}^{3} \mathrm{~m}_{\text {bed }}{ }^{-3} \mathrm{~h}^{-1}$, real waste gas (512 \pm 135 ppm N2 $\mathrm{O}, 26 \pm 16 \mathrm{ppm} \mathrm{NO}_{x}, 9 \pm 3 \mathrm{ppm} \mathrm{NH}_{3}, p=0.6 \mathrm{MPa}$ ). Points—experimental data; dashed line-model (Equation (2)).

As expected, the conversions achieved under laboratory and pilot-plant conditions vary due to different composition of the gaseous mixture, space velocities, pressure, and the effect of internal diffusion inherent to the use of commercial tablets. However, the order of catalysts' activities reached under laboratory and pilot-plant conditions also changed, which was unexpected. The highest $\mathrm{N}_{2} \mathrm{O}$ conversions under laboratory conditions were achieved using the $\mathrm{Cs} / \mathrm{Co}_{3} \mathrm{O}_{4}$ catalyst, but under pilot-plant conditions, comparable $\mathrm{N}_{2} \mathrm{O}$ conversions were obtained over the $\mathrm{K} / \mathrm{Co}_{4} \mathrm{MnAlO}_{x}$ catalyst, which was the worst performing under laboratory conditions.

Three questions arise: 
1. What are the reasons for the different activity order of commercially prepared catalyst tablets compared to laboratory-prepared samples?

2. Could our pilot-plant catalysts achieve higher activity $\left(\mathrm{N}_{2} \mathrm{O}\right.$ conversions)?

3. What are the theoretical limits of $\mathrm{N}_{2} \mathrm{O}$ conversions over catalyst tablets and how to approach them?

To answer the first question, catalytic experiments with commercially prepared tablets were carried out under laboratory conditions in simulated tail-gas (Figure 2). It is evident that the order of catalytic activities of commercial tablets was quite different to that in real waste gas (Figure 1b) but the same as for laboratory prepared catalysts tested in kinetic regime (Figure 1a). It is therefore implied that the different order of catalytic activities in the pilot-plant experiment (Figure 1b) was caused by the different conditions of the said experiment, particularly by the presence of $\mathrm{NO}_{x}$ gases, although their concentration was quite low (max $26 \mathrm{ppm}$ ). Significant inhibition of $\mathrm{N}_{2} \mathrm{O}$ decomposition caused by $\mathrm{NO}_{x}$ in the presence of cobalt catalysts modified by alkali promoters was previously reported $[2,8,9]$. The extent of the inhibiting effect depends on the alkali promoter type and its amount. The real tail gas also contained residual $\mathrm{NH}_{3}$. The effect of $\mathrm{NH}_{3}$ on the decomposition of $\mathrm{N}_{2} \mathrm{O}$ in the presence of cobalt catalysts was studied only sporadically; mainly on zeolites and to a lesser extent on oxidic catalysts $[10,11]$. The influence of $\mathrm{NH}_{3}$ in the feed gas was also studied in an individual experiment performed under laboratory conditions over $\mathrm{K} / \mathrm{Co}_{4} \mathrm{MnAlO}_{x}$-industry tablets [4]. It was found that ammonia oxidized to $\mathrm{N}_{2} \mathrm{O}, \mathrm{NO}, \mathrm{NO}_{2}$, and probably $\mathrm{N}_{2}$ (not measured), which means that ammonia can also contribute to the fluctuations of $\mathrm{NO}_{x}$ concentration present in the feed or can also increase $\mathrm{N}_{2} \mathrm{O}$ concentration at the reactor outlet. Laboratory and pilot-plant experiments were also performed under different pressures. Pilot-plant experiments were performed at higher pressure, which has a positive effect on the $\mathrm{N}_{2} \mathrm{O}$ catalytic decomposition rate [12].

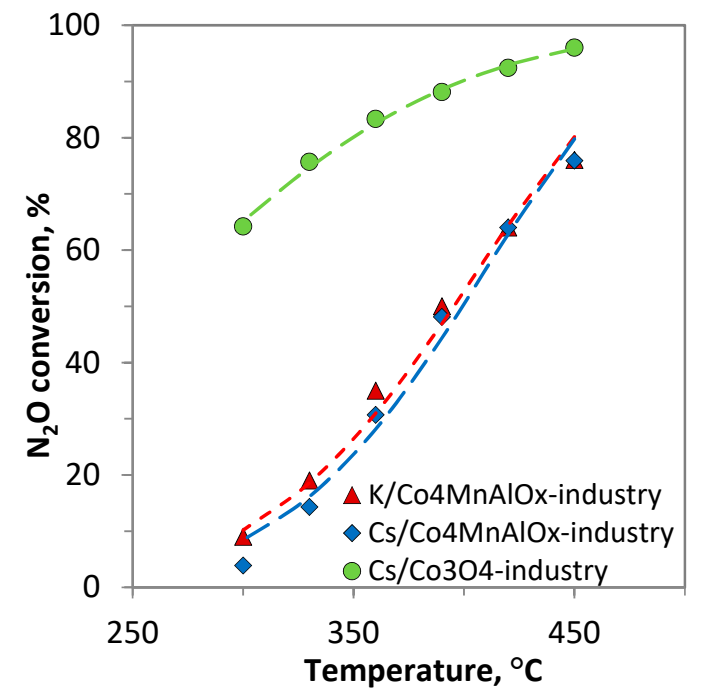

Figure 2. $\mathrm{N}_{2} \mathrm{O}$ catalytic decomposition over industrially prepared catalysts (tablets $5 \mathrm{~mm} \times 5 \mathrm{~mm}$ ) tested in laboratory conditions. Points-experimental data; dashed line-model (Equation (2)). Conditions: $\mathrm{VHSV}=3000 \mathrm{~m}^{3} \mathrm{~m}_{\text {bed }}{ }^{-3} \mathrm{~h}^{-1}, 1000 \mathrm{ppm} \mathrm{N}_{2} \mathrm{O}+5 \mathrm{~mol} \% \mathrm{O}_{2}+2 \mathrm{~mol} \% \mathrm{H}_{2} \mathrm{O}$ in $\mathrm{N}_{2}$.

To answer the second question, $\mathrm{N}_{2} \mathrm{O}$ decomposition was carried out in kinetic regime on laboratory and commercially prepared catalysts in grain form (Figure 3). First order kinetic constants using an ideal plug flow reactor model were also determined according to Equation (3), both for data in Figure 3a-c (grain catalysts) and for data in Figure 2 (tablet catalysts). Reaction rates (Equation (5)) and internal effectiveness factors (Equation (1)) were determined. A summary of the calculated kinetic parameters is shown in Table 1. 


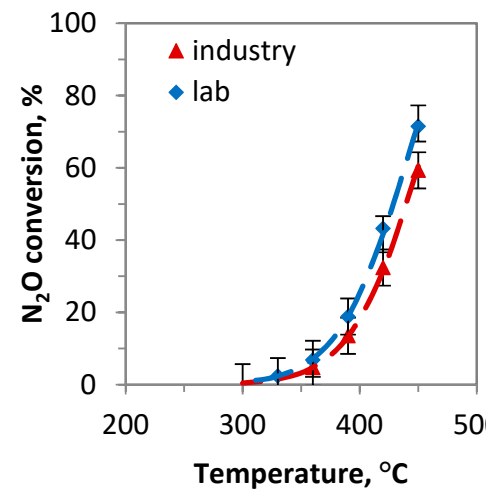

(a)

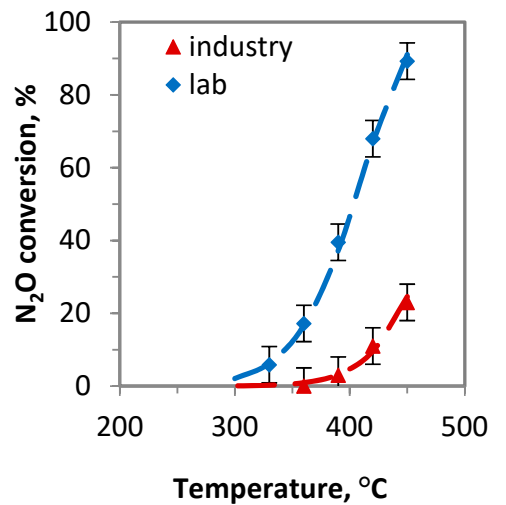

(b)

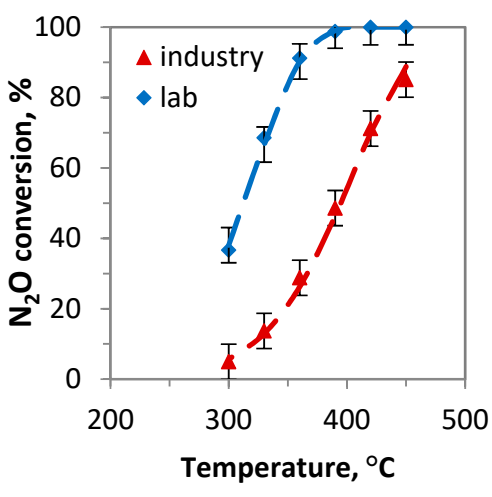

(c)

Figure 3. $\mathrm{N}_{2} \mathrm{O}$ decomposition over laboratory and commercially prepared catalysts in grain form: (a) $\mathrm{K} / \mathrm{Co}_{4} \mathrm{MnAlO}_{\mathrm{x}}$; (b) $\mathrm{Cs} / \mathrm{Co}_{4} \mathrm{MnAlO}_{\mathrm{x}}$; (c) $\mathrm{Cs} / \mathrm{Co}_{3} \mathrm{O}_{4}$. Points-experimental data; dashed line-model (Equation (2)). Conditions: 1000 ppm $\mathrm{N}_{2} \mathrm{O}+5 \mathrm{~mol} \% \mathrm{O}_{2}+2 \mathrm{~mol} \% \mathrm{H}_{2} \mathrm{O}$ in $\mathrm{N}_{2}, \mathrm{GHSV}=60,000 \mathrm{l} \mathrm{kg}^{-1} \mathrm{~h}^{-1}$.

Table 1. Kinetic constants and reaction rates of $\mathrm{N}_{2} \mathrm{O}$ catalytic decomposition over laboratory (grain form) and commercially prepared (grain and pellet forms) catalysts and estimated internal effectiveness factors. Conditions: $1000 \mathrm{ppm} \mathrm{N}_{2} \mathrm{O}+5 \mathrm{~mol}^{\circ} \mathrm{O}_{2}+2 \mathrm{~mol} \% \mathrm{H}_{2} \mathrm{O}$ in $\mathrm{N}_{2}, 390{ }^{\circ} \mathrm{C}$.

\begin{tabular}{lcccccc}
\hline \multirow{2}{*}{ Parameter/Catalyst } & \multicolumn{2}{c}{$\mathrm{K} / \mathrm{Co}_{4} \mathrm{MnAlO}_{x}$} & \multicolumn{2}{c}{$\mathrm{Cs} / \mathrm{Co}_{\mathbf{4}} \mathrm{MnAlO}_{x}$} & \multicolumn{2}{c}{$\mathrm{Cs} / \mathrm{Co}_{3} \mathrm{O}_{4}$} \\
\cline { 2 - 7 } & $\mathrm{Lab}$ & Industry & $\mathrm{Lab}$ & Industry & Lab & Industry \\
\hline$k_{\text {grain }}\left(\mathrm{m}^{3} \mathrm{~kg}^{-1} \mathrm{~s}^{-1}\right) \times 10^{3}$ & 3.47 & 2.42 & 8.38 & 0.51 & 73.15 & 11.09 \\
$k_{\text {grain }}{ }^{*}\left(\mathrm{~s}^{-1}\right) \times 10^{6}$ & 1.51 & 1.05 & 3.54 & 0.22 & 28.24 & 4.28 \\
$k_{\text {pellet }}\left(\mathrm{m}^{3} \mathrm{~kg}^{-1} \mathrm{~s}^{-1}\right) \times 10^{3}$ & - & 0.47 & - & 0.37 & - & 1.32 \\
$r_{\text {grain }}\left(\mathrm{mol} \mathrm{kg}^{-1} \mathrm{~h}^{-1}\right) \times 10^{2}$ & - & 3.37 & - & 0.75 & - & 12.12 \\
$r_{\text {pellet }}\left(\mathrm{mol} \mathrm{kg}^{-1} \mathrm{~h}^{-1}\right) \times 10^{2}$ & - & 0.70 & - & 0.55 & - & 1.90 \\
$\eta(-)^{2}$ & - & 0.21 & - & 0.73 & - & 0.15 \\
\hline
\end{tabular}

${ }^{1} 1$ st order kinetic constant $\left(\mathrm{s}^{-1}\right)$ determined according to Equation (4) ${ }^{2}$ Calculated as $\eta=r_{\text {grain }} / r_{\text {pellet }}$ for commercially prepared catalysts

By comparing $\mathrm{N}_{2} \mathrm{O}$ conversions, the values of $X_{\mathrm{A}}$ for the laboratory and commercially prepared $\mathrm{K} / \mathrm{Co}_{4} \mathrm{MnAlO}_{x}$ catalyst differ only by $12 \%$ maximum, at lower temperature the differences were within the margin of experimental error. This implies that the activity of active sites on the $\mathrm{K} / \mathrm{Co}_{4} \mathrm{MnAlO}_{x}$-industry catalyst is nearly the same as on the laboratory prepared sample, $\mathrm{K} / \mathrm{Co}_{4} \mathrm{MnAlO}_{x}$-lab and the reaction rate and kinetic constants of the tablet catalyst is lower mainly due to the inhibiting effect of internal diffusion. The main way to improve $\mathrm{N}_{2} \mathrm{O}$ conversion is therefore to increase the internal effectiveness factor, which in this case has a value of 0.21 . The possibilities of increasing the internal effectiveness factor are discussed in Chapter 3.

The situation is different with the $\mathrm{Cs} / \mathrm{Co}_{4} \mathrm{MnAlO}_{x}$ and $\mathrm{Cs} / \mathrm{Co}_{3} \mathrm{O}_{4}$ catalysts. The $\mathrm{N}_{2} \mathrm{O}$ conversion and kinetic constants in kinetic regime $\left(k_{\text {grain }}\right)$ are significantly lower when comparing the commercial and laboratory prepared samples. In the case of $\mathrm{Cs} / \mathrm{Co}_{3} \mathrm{O}_{4}$, the kinetic constant of the commercially prepared sample is six times lower and in the case of $\mathrm{Cs} / \mathrm{Co}_{4} \mathrm{MnAlO}_{x} 16$ times lower. This implies that the sites on the surface of commercially prepared catalysts are less active than those on the surface of laboratory prepared catalysts. The kinetic constants $k_{\text {pellet }}$ are lower than $k_{\text {grain }}$ of laboratory prepared samples due to the effect of internal diffusion and another effect, which caused the activity decrease of active sites. The $\mathrm{N}_{2} \mathrm{O}$ conversion using commercial tablets could be improved both by increasing the internal effectiveness factor and by increasing the activity of active sites to the same level as laboratory-prepared catalysts. It is important to note that by increasing activity, the internal effectiveness factor will decrease because parameters $\eta$ and $k$ are related to each other according to 
Equation (6)-(8). To determine the cause of different activities of $\mathrm{Cs} / \mathrm{Co}_{4} \mathrm{MnAlO} \mathrm{O}_{x}$ and $\mathrm{Cs} / \mathrm{Co}_{3} \mathrm{O}_{4}$ catalysts, a basic characterization of laboratory and commercially prepared catalysts was performed.

\subsection{Physicochemical Properties of Catalysts}

Basic physicochemical properties of laboratory and commercially prepared catalysts are shown in Table 2. Analysis of chemical composition shows that the molar ratio of $\mathrm{Co}: \mathrm{Mn}: \mathrm{Al}$ is basically the same for laboratory and commercially prepared $\mathrm{Co}_{4} \mathrm{MnAlO}_{x}$ samples modified by $\mathrm{K}$ and $\mathrm{Cs}$ and is close to the ratio of 4:1:1, which was the aim during synthesis.

Table 2. Physicochemical properties of laboratory and commercially prepared catalysts.

\begin{tabular}{|c|c|c|c|c|c|c|c|}
\hline & & \multicolumn{2}{|l|}{$\mathrm{K} / \mathrm{Co}_{4} \mathrm{MnAlO}_{\mathrm{x}}$} & \multicolumn{2}{|l|}{$\mathrm{Cs} / \mathrm{Co}_{4} \mathrm{MnAlO}_{\mathrm{x}}$} & \multicolumn{2}{|l|}{$\mathrm{Cs} / \mathrm{Co}_{3} \mathrm{O}_{4}$} \\
\hline & & Industry & Lab & Industry & Lab & Industry & Lab \\
\hline \multirow{5}{*}{$\begin{array}{l}\text { Chemical } \\
\text { composition } \\
(\mathrm{wt} \%)\end{array}$} & $\mathrm{Co}$ & 45 & 49.6 & 45.7 & 46.0 & 63.4 & 68.0 \\
\hline & $\mathrm{Mn}$ & 9.3 & 13.3 & 8.5 & 10.6 & - & - \\
\hline & $\mathrm{Al}$ & 5.2 & 8.9 & 5.1 & n.d. & - & - \\
\hline & $\mathrm{K} / \mathrm{Cs}$ & 1.3 & 1.8 & 3.4 & 3.5 & 1.0 & 1.0 \\
\hline & $\mathrm{Na}$ & 0.1 & 0.1 & 0.1 & 0.5 & n.d. & 0.04 \\
\hline \multicolumn{2}{|l|}{$\begin{array}{l}\text { Co:Mn:Al } \\
\text { mol. ratio }\end{array}$} & $4: 0.7: 0.7$ & $\begin{array}{l}4: 1.2: \\
1.6\end{array}$ & $4: 0.9: 1.0$ & $\begin{array}{l}4: 1: \\
\text { n.d. }\end{array}$ & - & - \\
\hline \multirow{2}{*}{\multicolumn{2}{|c|}{$\begin{array}{l}S_{\text {BET }}\left(\mathrm{m}^{2} / \mathrm{g}\right) \\
r(\mathrm{~nm})^{1}\end{array}$}} & 93 & 98 & 68 & 86 & 20 & 13 \\
\hline & & 3.8 & 12.3 & 5.3 & 7.1 & 10.2 & 13.5 \\
\hline \multicolumn{2}{|c|}{$\begin{array}{l}\text { Alkali metal normalized } \\
\left.\text { loading (atoms } / \mathrm{nm}^{2}\right)^{2}\end{array}$} & 1.9 & 2.8 & 2.1 & 1.8 & 2.4 & 3.5 \\
\hline \multirow{3}{*}{\multicolumn{2}{|c|}{$\begin{array}{l}\text { Phase composition } \\
L_{c}(\mathrm{~nm}) \\
a(\mathrm{~nm})\end{array}$}} & Spinel, graphite & Spinel & Spinel, graphite & Spinel & Spinel, graphite & Spinel \\
\hline & & 9 & 7 & 13 & 7 & 18 & \\
\hline & & 0.8118 & 0.8110 & 0.8111 & 0.8116 & 0.8084 & 0.8086 \\
\hline \multicolumn{2}{|l|}{$T_{\max }\left({ }^{\circ} \mathrm{C}\right)^{3}$} & $272 ; 377$ & $\begin{array}{l}320 \\
361\end{array}$ & $284 ; 390$ & $\begin{array}{l}168 ; \\
274 ; \\
359\end{array}$ & $352 ; 389$ & 370 \\
\hline \multicolumn{2}{|c|}{$\mathrm{H}_{2}(\mathrm{mmol} / \mathrm{g})^{4}$} & 4.5 & 4.8 & 4.2 & 4.1 & 14 & 12.9 \\
\hline
\end{tabular}

For catalytic activity, the content of alkali promoters is important $[2,13,14]$. The amount of Cs in laboratory and commercially prepared samples is the same and close to the optimal value of $3.5 \mathrm{wt} \%$ for $\mathrm{Co}_{4} \mathrm{MnAlO}_{\mathrm{x}}$ [1] and $1 \mathrm{wt} \%$ for $\mathrm{Co}_{3} \mathrm{O}_{4}$ [3]. In the case of $\mathrm{K} / \mathrm{Co}_{4} \mathrm{MnAlO}_{x}$, the intention was to prepare the commercial catalyst with $\mathrm{K}$ content of $1.8 \mathrm{wt} \%$, which proved to be the most active in our previous work [2]. Here it was found that the optimal $\mathrm{K}$ content (determined by atomic emission spectroscopy, AES) leading to the highest $\mathrm{N}_{2} \mathrm{O}$ conversion was $0.9-1.6 \mathrm{wt} \% \mathrm{~K}$ in an inert gas and $1.6-2.8 \mathrm{wt} \% \mathrm{~K}$ in the presence of $\mathrm{O}_{2}$ and $\mathrm{H}_{2} \mathrm{O}$. The analysis of $\mathrm{K}$ content in a commercially prepared sample showed a lower $\mathrm{K}$ content, probably due to inhomogeneity, which is a known disadvantage of the impregnation method. All catalysts contained sodium residuals $(0.04-0.50 \mathrm{wt} \%)$ from the preparation procedure. Since our recent results showed that to affect catalytic activity, significantly higher Na content $(>1.15 \mathrm{wt} \%)$ is necessary [8], we do not expect residual sodium to influence catalytic activity.

The comparison of the specific surface areas of laboratory and commercially prepared samples (Table 2) shows that, in terms of specific surface area, the transfer of catalyst synthesis to a larger scale was successful. Catalyst synthesis on a larger commercial scale led to a lower mean pore size for all three catalysts, which was caused by the use of high pressure during tabletization [15]. It was found out that on increasing pressure (up to $10 \mathrm{MPa}$ ) during tabletization of the catalyst matter (grains of defined size), the diameter of mesopores decreased, while the specific surface area stayed constant up to $8 \mathrm{MPa}$. 
Measured nitrogen adsorption-desorption isotherms of commercially prepared catalysts (Figure 4a) indicate that there is a big difference between the individual samples. While the isotherms of $\mathrm{K} / \mathrm{Co}_{4} \mathrm{MnAlO}_{x}$-industry and $\mathrm{Cs} / \mathrm{Co}_{4} \mathrm{MnAlO}_{x}$-industry correspond to the mesoporous material with generally larger mesopores, the isotherm of $\mathrm{Cs} / \mathrm{Co}_{3} \mathrm{O}_{4}$ corresponds to macroporous material. Comparing $\mathrm{K} / \mathrm{Co}_{4} \mathrm{MnAlO}_{x}$-industry and $\mathrm{Cs} / \mathrm{Co}_{4} \mathrm{MnAlO}_{x}$-industry samples, $\mathrm{K} / \mathrm{Co}_{4} \mathrm{MnAlO}_{x}$-industry possesses smaller mesopores than $\mathrm{Cs} / \mathrm{Co}_{4} \mathrm{MnAlO}_{x}$-industry (Figure $4 \mathrm{~b}$ ) which is at comparable total pore volumes reflected by the higher specific surface area of the pores of $\mathrm{K} / \mathrm{Co}_{4} \mathrm{MnAlO}_{x}$-industry.

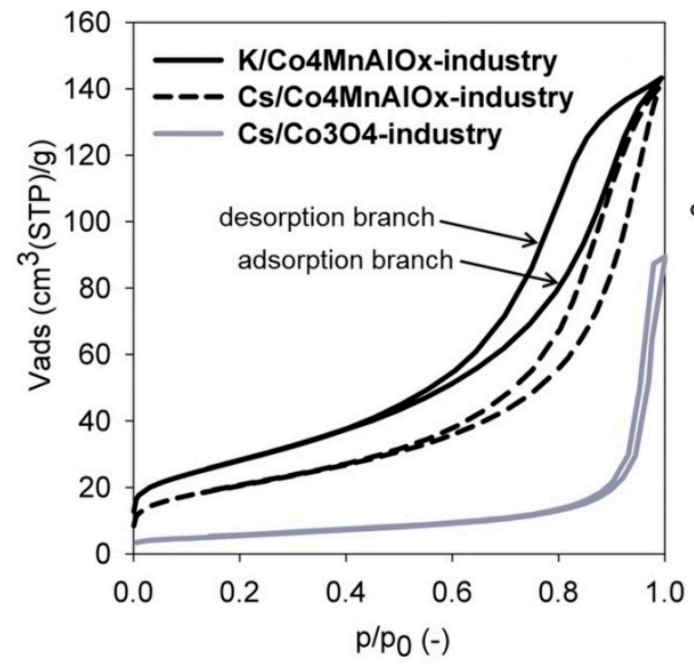

(a)

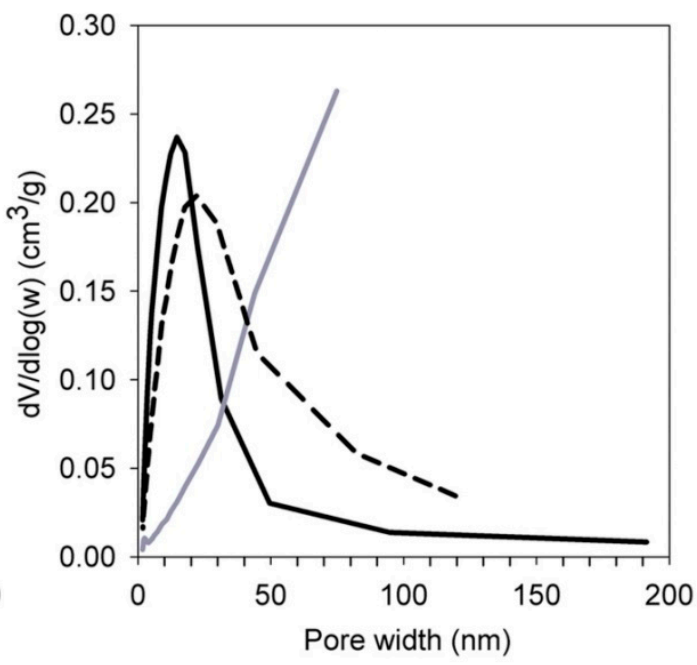

(b)

Figure 4. (a) Measured nitrogen adsorption-desorption isotherms and (b) evaluated pore-size distributions of commercially prepared catalysts.

All commercially prepared samples do not possess any micropores, thus, the values of the micropore volume and mesopore surface area are not shown in Table 3. The determined textural properties of the commercially prepared catalysts are summarized in Table 3.

Table 3. Textural properties of commercially prepared catalysts.

\begin{tabular}{|c|c|c|c|c|c|}
\hline Catalyst & $\begin{array}{c}S_{\mathrm{BET}} \\
\left(\mathrm{m}^{2} / \mathrm{g}\right)\end{array}$ & $\begin{array}{c}V_{\text {net }} \\
\left(\mathrm{cm}^{3} \text { liq } / \mathrm{g}\right)\end{array}$ & $\begin{array}{c}\text { Pore width } \\
\text { (nm) }\end{array}$ & $\begin{array}{c}\rho_{c} \\
\left(\mathrm{~kg} \mathrm{~m}^{-3}\right)\end{array}$ & $\begin{array}{l}\varepsilon_{p} \\
(-)\end{array}$ \\
\hline $\mathrm{K} / \mathrm{Co}_{4} \mathrm{MnAlO}_{x}$-industry & 101 & 0.220 & 15 & 2300 & 0.48 \\
\hline $\mathrm{Cs} / \mathrm{Co}_{4} \mathrm{MnAlO}_{x}$-industry & 73 & 0.217 & 22 & 2370 & 0.50 \\
\hline $\mathrm{Cs} / \mathrm{Co}_{3} \mathrm{O}_{4}$-industry & 19 & 0.138 & above 75 & 2590 & 0.47 \\
\hline
\end{tabular}

Results of phase composition are summarized in Figure 5 and Table 2. Measured diffraction lines characteristic for a cobalt spinel structure were indexed within the $F d 3 m$ space group and this structure was confirmed in all investigated samples as the major phase. Graphite was also found as a minor phase in all industrially prepared catalysts, together with the spinel phase, since graphite was added to the catalyst matter for ease of forming. Graphite line was not observed in the catalysts used in the long-term pilot plant testing (not shown here), confirming combustion of graphite during the catalytic test [4]. Small un-labelled diffractions correspond to the Kbeta line of the used X-ray radiation source. All $\mathrm{Co}_{4} \mathrm{MnAlO}_{x}$ samples have slightly higher values of cell parameters $(a)$ in comparison to pure $\mathrm{Co}_{3} \mathrm{O}_{4}$ due to incorporation of $\mathrm{Mn}$ and $\mathrm{Al}$ ions into the spinel structure. In addition, samples with $\mathrm{Co}_{4} \mathrm{MnAlO}_{x}$ active phase have nanocrystalline structure and higher surface area in comparison to samples with $\mathrm{Co}_{3} \mathrm{O}_{4}$. Crystallite sizes (expressed as mean coherent domain size $L_{\mathrm{c}}$ ) correlate with the determined surface area; the smaller the crystallite size the larger is the surface area. Potassium doped samples $\mathrm{K} / \mathrm{Co}_{4} \mathrm{MnAlO}_{x}$-lab and -industry exhibit approximately similar size for coherent domain and 
surface area. In the case of cesium doped $\mathrm{Cs} / \mathrm{Co}_{4} \mathrm{MnAlO}_{x}$ samples, the laboratory prepared catalyst has a less crystalline structure and higher surface area in comparison with the commercially prepared sample. Laboratory prepared cesium doped cobalt oxide $\mathrm{Cs} / \mathrm{Co}_{3} \mathrm{O}_{4}$ exhibits the highest value of coherent domain size and the lowest specific surface area of all tested samples.

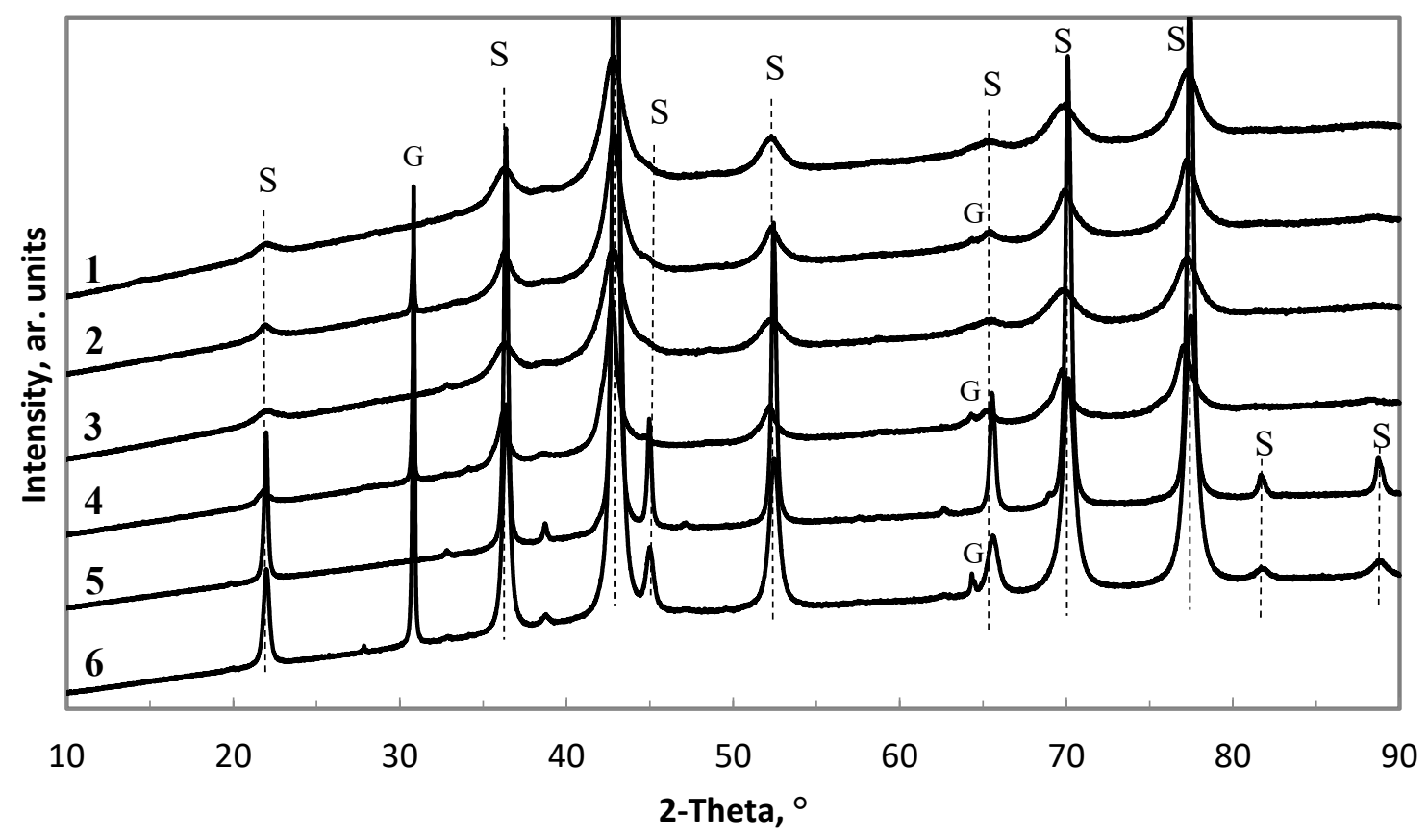

Figure 5. XRD patterns of the laboratory and commercially prepared catalysts: (1) $\mathrm{K} / \mathrm{Co}_{4} \mathrm{MnAlO}_{x}$-lab; (2) $\mathrm{K} / \mathrm{Co}_{4} \mathrm{MnAlO}_{x}$-industry; (3) $\mathrm{Cs} / \mathrm{Co}_{4} \mathrm{MnAlO}_{x}$-lab; (4) $\mathrm{Cs} / \mathrm{Co}_{4} \mathrm{MnAlO}_{x}$-industry; (5) $\mathrm{Cs} / \mathrm{Co}_{3} \mathrm{O}_{4}$-lab;

(6) $\mathrm{Cs} / \mathrm{Co}_{3} \mathrm{O}_{4}$-industry. Phase designation: $\mathrm{S}-$ spinel, $\mathrm{G}$ - graphite.

The reduction patterns of catalysts prepared commercially and in the laboratory are shown in Figure 6. Since the catalytic reaction proceeds up to $450{ }^{\circ} \mathrm{C}$, only species reducible in this temperature region (low temperature region) can contribute to the catalyst activity and for that reason only the low temperature area of TPR- $\mathrm{H}_{2}$ is shown. For samples containing only cobalt species (besides alkali promoter), the main reduction peak can be ascribed to the reduction of $\mathrm{Co}^{\mathrm{III}} \rightarrow \mathrm{Co}^{\mathrm{II}} \rightarrow \mathrm{Co}^{0}$. In the case of $\mathrm{Cs} / \mathrm{Co}_{3} \mathrm{O}_{4}$, both reduction processes overlap (more for the laboratory prepared catalyst), suggesting not only different primary particle size but also different shapes of cobalt spinel nanocrystals [16]. The catalysts containing cobalt, manganese, and aluminum are reduced in two main temperature regions, $200-430{ }^{\circ} \mathrm{C}$ and $>430^{\circ} \mathrm{C}$. Both reduction peaks consist of overlapping peaks corresponding to the reduction of more species. The low-temperature reduction peak also represents, besides the reduction of cobalt species in a segregated $\mathrm{Co}_{3} \mathrm{O}_{4}$-like phase, the reduction of $\mathrm{Mn}^{\mathrm{IV}}$ to $\mathrm{Mn}^{\mathrm{III}}$ oxides, while $\mathrm{Mn}^{\mathrm{III}} \rightarrow \mathrm{Mn}^{\mathrm{II}}$ reduction can take place in both temperature regions [17]. The high temperature peak was attributed to the reduction of $\mathrm{Co}$ and $\mathrm{Mn}$ ions surrounded by $\mathrm{Al}$ ions in the spinel-like phase [8]. The presence of alkali metals in the mixed oxides caused the formation of an easily reducible species (Co and/or Mn) manifested as a low temperature shoulder visible especially in $\mathrm{Co}_{4} \mathrm{MnAlO}_{x}$ containing samples.

The quantitative data (Table 2) confirmed a comparable amount of reducible species (in the temperature range of $25-450{ }^{\circ} \mathrm{C}$ ) in samples prepared commercially and in laboratory conditions, while samples containing only $\mathrm{Co}_{3} \mathrm{O}_{4}$ active phase possessed higher amounts of reducible components in comparison with $\mathrm{Co}_{4} \mathrm{MnAlO}_{x}$ containing samples. The TPR profile shapes are similar for therelevant samples prepared commercially and in the laboratory; only small shifts are seen-the biggest changes are visible for $\mathrm{Cs} / \mathrm{Co}_{4} \mathrm{MnAlO}_{x}$ where the commercially prepared catalyst exhibits inferior reducibility. Since the reducibility of the cobalt and manganese species is affected by the primary particle size [18], 
the visible changes are probably connected with different crystallite sizes as was also proved by the XRD results and the inhomogeneity of samples rather than a different chemico-electronic environment.

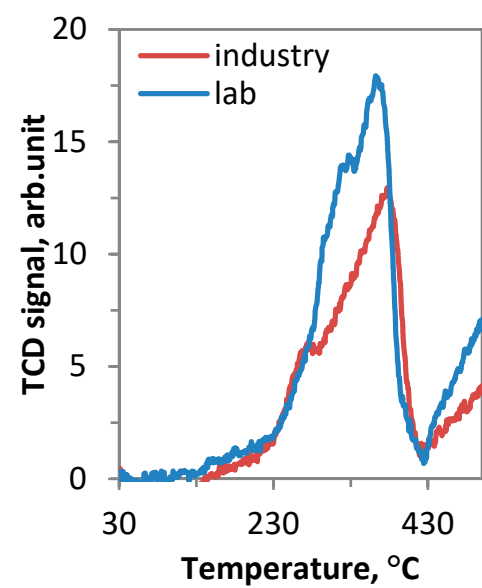

(a)

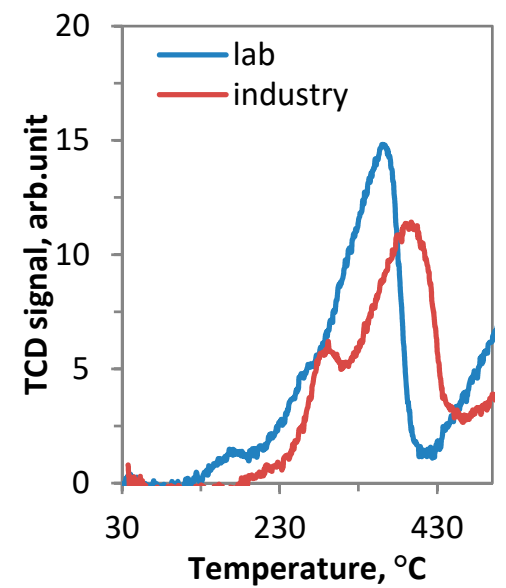

(b)

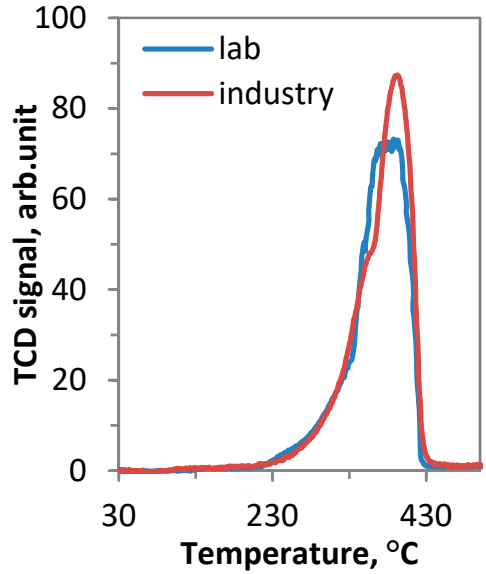

(c)

Figure 6. TPR- $\mathrm{H}_{2}$ of the laboratory and commercially prepared catalysts: (a) $\mathrm{K} / \mathrm{Co}_{4} \mathrm{MnAlO}_{x}$; (b) $\mathrm{Cs} / \mathrm{Co}_{4} \mathrm{MnAlO}_{x}$; (c) $\mathrm{Cs} / \mathrm{Co}_{3} \mathrm{O}_{4}$.

Published results imply that normalized loading of alkali metals (atoms $/ \mathrm{nm}^{2}$ ) on the catalyst surface is an important parameter of cobalt-based catalysts $[19,20]$. The reason is the electronic nature of the potassium and cesium promotion effect based on the formation of surface dipoles influencing the electron density of cobalt and manganese cations, which was confirmed by the direct correlation between $\mathrm{N}_{2} \mathrm{O}$ conversion and surface work function catalysts [19]. Figure 7 shows the dependence of $\mathrm{N}_{2} \mathrm{O}$ conversion on the normalized loading of $\mathrm{K}$ and $\mathrm{Cs}$ over $\mathrm{Co}_{4} \mathrm{MnAlO}_{x}$ and $\mathrm{Co}_{3} \mathrm{O}_{4}$, utilizing data on the optimization of $\mathrm{K}[2]$ and $\mathrm{Cs}[1]$ content in $\mathrm{Co}_{4} \mathrm{MnAlO}_{\mathrm{x}}$ mixed oxide and Cs content in $\mathrm{Co}_{3} \mathrm{O}_{4}[3]$.

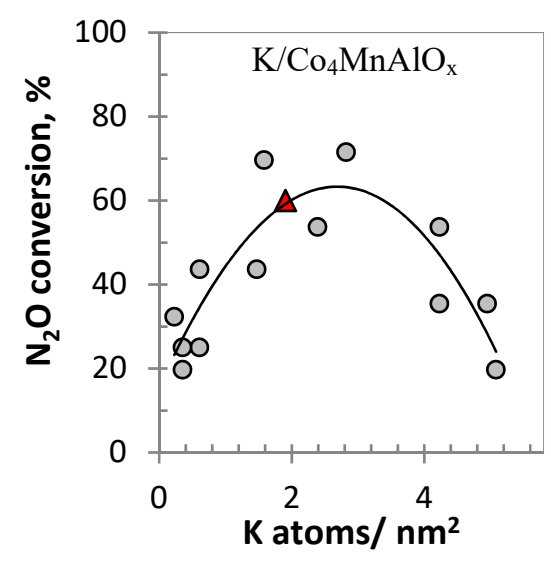

(a)

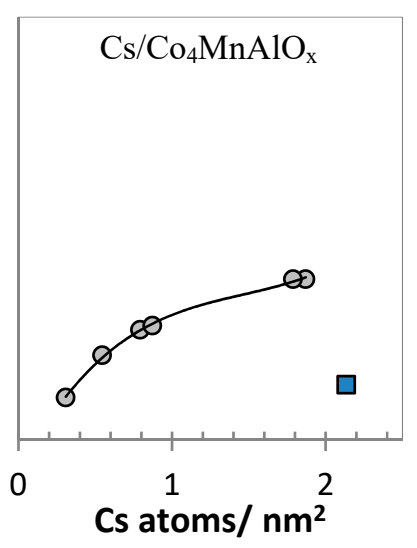

(b)

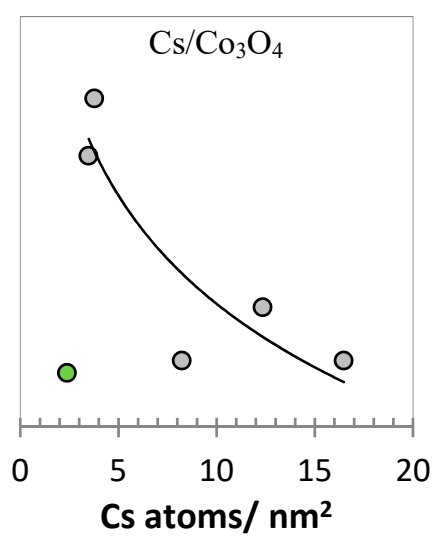

(c)

Figure 7. Dependence of $\mathrm{N}_{2} \mathrm{O}$ conversion on alkali metal loading. Conditions: $1000 \mathrm{ppm} \mathrm{N}_{2} \mathrm{O}+5$ mol $\% \mathrm{O}_{2}+2 \mathrm{~mol} \% \mathrm{H}_{2} \mathrm{O}$ in $\mathrm{N}_{2}$. O Laboratory prepared catalysts. (a) $450{ }^{\circ} \mathrm{C}, \mathrm{GHSV}=20,000 \mathrm{l} \mathrm{kg}^{-1} \mathrm{~h}^{-1}$, $\Delta \mathrm{K} / \mathrm{Co}_{4} \mathrm{MnAlO}_{x}$-industry; (b) $390{ }^{\circ} \mathrm{C}, \mathrm{GHSV}=60,0001 \mathrm{~kg}^{-1} \mathrm{~h}^{-1}$, 口 Cs $/ \mathrm{Co}_{4} \mathrm{MnAlO}_{x}$-industry; (c) $330{ }^{\circ} \mathrm{C}, \mathrm{GHSV}=60,0001 \mathrm{~kg}^{-1} \mathrm{~h}-1, \mathrm{O} \mathrm{Cs} / \mathrm{Co}_{3} \mathrm{O}_{4}$-industry.

It is evident that the conversion of $\mathrm{N}_{2} \mathrm{O}$ in the presence of $\mathrm{K} / \mathrm{Co}_{4} \mathrm{MnAlO}_{x}$ reaches an optimum at 1.6-2.8 K atoms $/ \mathrm{nm}^{2}$, while in the case of $\mathrm{Cs} / \mathrm{Co}_{4} \mathrm{MnAl}$ the conversion of $\mathrm{N}_{2} \mathrm{O}$ increases with higher $\mathrm{Cs}$ loading in the observed concentration range and decreases with increasing $\mathrm{Cs}$ loading on $\mathrm{Co}_{3} \mathrm{O}_{4}$. Loading of $\mathrm{K}$ and Cs in samples prepared commercially and in the laboratory are listed in Table 2. In the case of commercially prepared $\mathrm{K} / \mathrm{Co}_{4} \mathrm{MnAlO}_{x}$, the loading of $\mathrm{K}$ is in the optimal range, while in 
the case of $\mathrm{Cs} / \mathrm{Co}_{4} \mathrm{MnAlO}_{x}$-industry the $\mathrm{Cs}$ loading is higher than in the laboratory prepared sample and the dependence of $\mathrm{N}_{2} \mathrm{O}$ conversion on Cs loading in this region is unknown. On the contrary, the Cs loading in $\mathrm{Cs} / \mathrm{Co}_{3} \mathrm{O}_{4}$-industry is lower than 3.5 , the value that was determined for $\mathrm{Cs} / \mathrm{Co}_{3} \mathrm{O}_{4}$-lab. It is important to mention that the reproducibility of the normalized loading during the preparation was difficult. The reason is that even relatively small changes in the specific surface area and/or the alkali metal content caused a change in the normalized loading, which is already significant due to the relatively narrow optimal range of its value.

The characterization results of laboratory and commercially prepared catalysts showed good correlation with catalytic properties in the kinetic regime:

- The $\mathrm{K} / \mathrm{Co}_{4} \mathrm{MnAlO}_{x}$ catalysts demonstrated very similar characteristics for laboratory and commercially prepared samples. Both samples have the same chemical and phase composition; they differ slightly in $\mathrm{K}$ content, which is however still in the optimal range, similar to $\mathrm{K}$ normalized loading (atoms $/ \mathrm{nm}^{2}$ ). The samples have the same specific surface areas and crystallite sizes (within the margin of error), which is manifested in also having similar reducibilities.

- The situation is different in the case of Cs-modified catalysts. Here the characterization results differ more significantly, which is reflected by the differences in conversion and kinetic constant values determined in the kinetic regime (Table 1, Figure 3).

- While the commercially prepared $\mathrm{Cs} / \mathrm{Co}_{4} \mathrm{MnAlO}_{x}$ has the same chemical and phase composition as the laboratory prepared sample, its crystallite size is $1.8 \times$ higher than for the laboratory prepared sample, which leads to both lower specific surface area and worse reducibility. Our previous work proved a direct relationship between the crystallite size and reducibility of $\mathrm{Co}$ and $\mathrm{Mn}$ in their higher oxidation states $\left(\mathrm{Co}^{3+}, \mathrm{Mn}^{4+}\right)$ in $\mathrm{Co}_{4} \mathrm{MnAlO}_{x}$ [17]. Taking into account that the slowest step of $\mathrm{N}_{2} \mathrm{O}$ decomposition is the desorption of oxygen from the catalyst surface connected to the reduction of active sites, worse reducibility of $\mathrm{Co}^{3+}$ and probably even $\mathrm{Mn}^{4+}$ (corresponding to the temperature maxima of the 1st reduction peak in TPR- $\mathrm{H}_{2}$ ) causes a decrease in $\mathrm{N}_{2} \mathrm{O}$ conversion. This was observed in the case of the commercially prepared $\mathrm{Cs} / \mathrm{Co}_{4} \mathrm{MnAlO}_{x}$.

- Similarly, the commercially prepared $\mathrm{Cs} / \mathrm{Co}_{3} \mathrm{O}_{4}$ catalyst has the same chemical and phase composition as the laboratory prepared sample. However, the situation regarding crystallite size is completely reversed compared to $\mathrm{Cs} / \mathrm{Co}_{4} \mathrm{MnAlO}_{x}$. The commercially prepared $\mathrm{Cs} / \mathrm{Co}_{3} \mathrm{O}_{4}$ catalyst's crystallite size is $2.7 \times$ lower than for the laboratory prepared sample, which corresponds with its higher specific surface area and lower normalized loading of Cs (atoms $/ \mathrm{nm}^{2}$ ). The reducibility of $\mathrm{Co}^{3+}$ and $\mathrm{Co}^{2+}$ cannot be determined due to TPR peaks overlapping, but the results indicate different shapes of the cobalt spinel nanocrystals, which affect the catalytic activity [16].

\section{Discussion}

As determined in Section 2.1, we assume that the $k$ value for the $\mathrm{K} / \mathrm{Co}_{4} \mathrm{MnAlO}_{x}$ catalyst in the kinetic regime is nearly at its maximum and the increase of $\mathrm{N}_{2} \mathrm{O}$ conversion on the tablet catalyst can be theoretically achieved mainly by accelerating the diffusion of reaction mixture molecules in the catalyst's pores. In contrast to this, the increase of $\mathrm{N}_{2} \mathrm{O}$ conversion on the $\mathrm{Cs} / \mathrm{Co}_{4} \mathrm{MnAlO}_{x}$ and $\mathrm{Cs} / \mathrm{Co}_{3} \mathrm{O}_{4}$ catalysts is possible, besides accelerating internal diffusion, also by optimization of physico-chemical characteristics (crystallite size, reducibility, Cs loading and shape of Co nanocrystals) as described in Section 2.2.

The aim of this part of the paper is to show the limits of increasing conversion by intensification of mass transfer inside pores by tuning the morphology of the catalysts (pore diameter, porosity, and tortuosity) studied for $\mathrm{N}_{2} \mathrm{O}$ decomposition.

The measure of reaction rate limitation by internal diffusion is the internal effectiveness factor (Equation (1)). Its dependence on catalyst morphology is represented by the effective diffusion coefficient $D_{\text {eff }}$ (Equation (10)), which is influenced by catalyst porosity, tortuosity, and by the ratio of 
pore diameter and the reacting molecule's dimension. Table 4 shows the calculated values of the overall diffusivity of $\mathrm{N}_{2} \mathrm{O}$ in a multicomponent mixture $(\bar{D})$ according to Equation (11) and the contributions of molecular $\left(D_{\text {mol }}\right)$ and Knudsen $\left(D_{k, N_{2} O}\right)$ diffusivity according to Equations (12)-(13). The results imply that the prevalent transport mechanism inside pores is Knudsen diffusion, which means that the rate of internal diffusion can be theoretically increased by increasing the pore size and increasing the value of $D_{\mathrm{k}}$ for all three catalysts. In addition, the mass transport inside the pores can be improved by increasing the $\varepsilon_{\mathrm{p}} / q$ ratio, i.e. increasing the porosity of the tablets and decreasing the pore tortuosity and thus increasing $D_{\text {eff }}$.

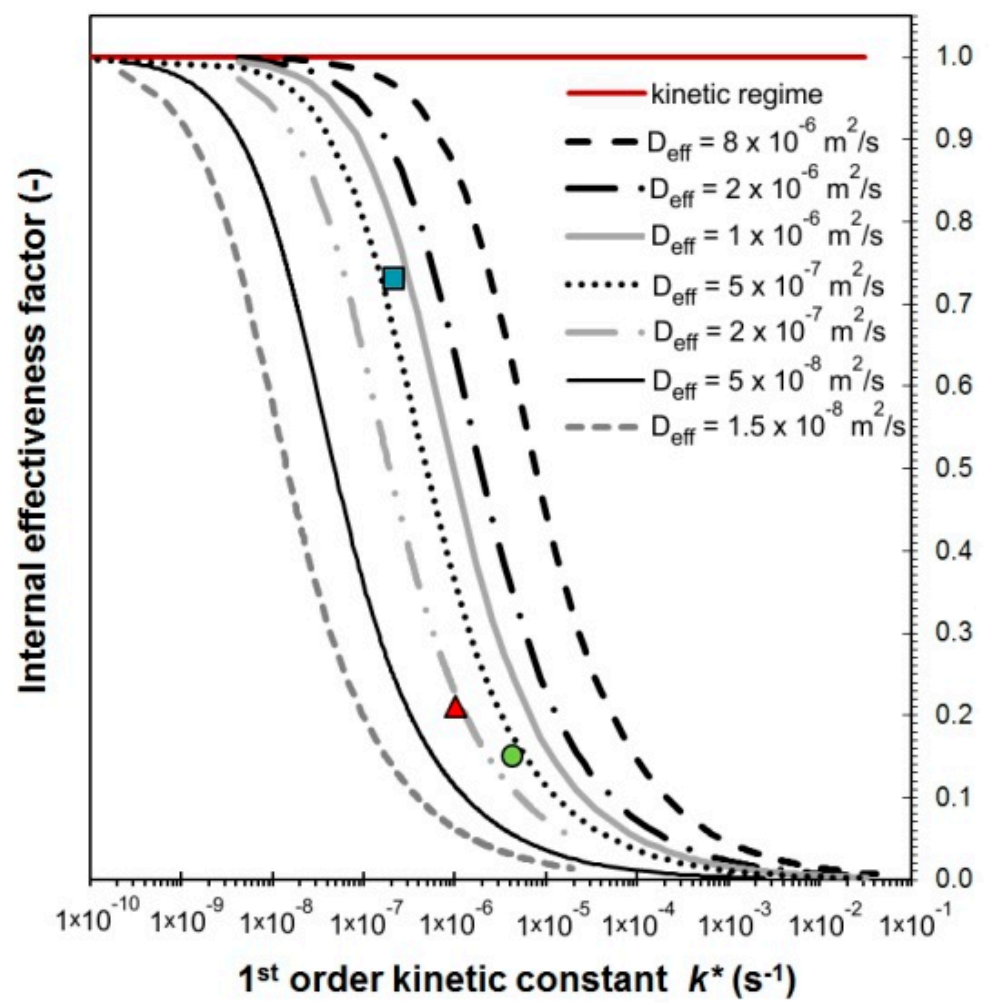

Figure 8. Dependence of internal effectiveness factor on the intrinsic 1st order kinetic constant for different values of effective diffusion coefficients. Calculated for tablets $5.1 \mathrm{~mm} \times 5.1 \mathrm{~mm}$. $\Delta$ $\mathrm{K} / \mathrm{Co}_{4} \mathrm{MnAlO}_{x}$-industry; $\square \mathrm{Cs} / \mathrm{Co}_{4} \mathrm{MnAlO}_{x}$-industry; O $\mathrm{Cs} / \mathrm{Co}_{3} \mathrm{O}_{4}$-industry.

Table 4. Diffusion coefficients and tortuosity determined for commercially prepared catalysts. Parameters: $390{ }^{\circ} \mathrm{C}, 150 \mathrm{kPa}$, mean pore diameter, model gas mixture $1000 \mathrm{ppm} \mathrm{N}_{2} \mathrm{O}+5 \mathrm{~mol} \%$ $\mathrm{O}_{2}+2 \mathrm{~mol} \% \mathrm{H}_{2} \mathrm{O}$ in $\mathrm{N}_{2}$, catalysts in tablets $5.1 \mathrm{~mm} \times 5.1 \mathrm{~mm}$.

\begin{tabular}{llll}
\hline Parameter/Catalyst & $\mathbf{K} / \mathrm{Co}_{4} \mathbf{M n A l O}_{\mathbf{x}}$-Industry & $\mathrm{Cs} / \mathrm{Co}_{\mathbf{4}} \mathbf{M n A 1 O} \mathbf{O}_{\mathbf{x}}$-Industry & $\mathrm{Cs} / \mathrm{Co}_{3} \mathrm{O}_{4}$-Industry \\
\hline$D_{\mathrm{k}}\left(\mathrm{m}^{2} \mathrm{~s}^{-1}\right)$ & $2.82 \cdot 10^{-6}$ & $4.14 \cdot 10^{-6}$ & $1.41 \cdot 10^{-5}$ \\
$D_{\mathrm{mol}}\left(\mathrm{m}^{2} \mathrm{~s}^{-1}\right)$ & $7 \cdot 10^{-3}$ & $7 \cdot 10^{-3}$ & $7 \cdot 10^{-3}$ \\
$\bar{D}\left(\mathrm{~m}^{2} \mathrm{~s}^{-1}\right)$ & $2.82 \cdot 10^{-6}$ & $4.14 \cdot 10^{-6}$ & $1.41 \cdot 10^{-5}$ \\
$D_{\text {eff }}\left(\mathrm{m}^{2} \mathrm{~s}^{-1}\right)^{1}$ & $2 \cdot 10^{-7}$ & $7.5 \cdot 10^{-7}$ & $3.5 \cdot 10^{-7}$ \\
$X_{\mathrm{N}_{2} \mathrm{O}}$ model $(\%)^{2}$ & 50 & 39 & 85 \\
$X_{\mathrm{N}_{2} \mathrm{O}}$ experiment $(\%)^{3}$ & 50 & 48 & 88 \\
$q^{4}(-)$ & 6.78 & 2.76 & 18.92 \\
$\varepsilon_{\mathrm{p}} / q(-)$ & 0.07 & 0.18 & 0.02 \\
\hline
\end{tabular}

\footnotetext{
${ }^{1}$ Determined from Figure 8 for $\eta$ evaluated from experimental data mentioned in Table $1^{2}$ Determined from Figure 9

${ }^{3}$ Experimental data of $\mathrm{N}_{2} \mathrm{O}$ decomposition over commercial tablets measured in the laboratory at $390{ }^{\circ} \mathrm{C}$ and VHSV $=3000 \mathrm{~m}^{3} \mathrm{~m}_{\text {bed }}{ }^{-3} \mathrm{~h}^{-1}$ (Figure 2) ${ }^{4}$ Tortuosity calculated from Equation (10) using experimentally determined porosity (Table 3 )
} 


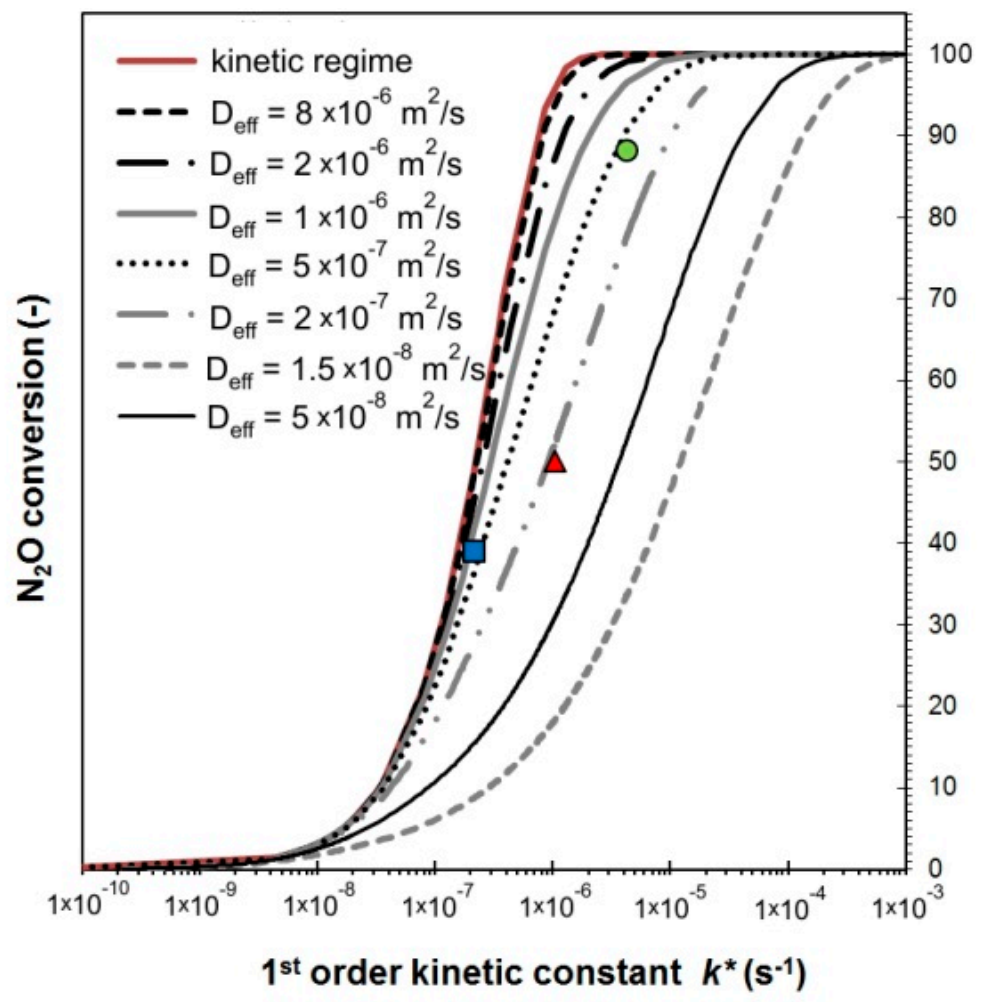

Figure 9. Dependence of theoretically achievable $\mathrm{N}_{2} \mathrm{O}$ conversion on the 1st order kinetic constant in kinetic regime. Conversion of $\mathrm{N}_{2} \mathrm{O}$ calculated for VHSV $=3000 \mathrm{~m}^{3} \cdot \mathrm{m}_{\text {bed }}{ }^{-3} \cdot \mathrm{h}^{-1}$ and tablets $5.1 \mathrm{~mm} \times 5.1 \mathrm{~mm} . \Delta \mathrm{K} / \mathrm{Co}_{4} \mathrm{MnAlO}_{x}$-industry; $\square \mathrm{Cs} / \mathrm{Co}_{4} \mathrm{MnAlO}$-industry; $\mathrm{O} \mathrm{Cs} / \mathrm{Co}_{3} \mathrm{O}_{4}$-industry.

The diagram in Figure 8 shows the dependence of the internal effectiveness factor on the 1st order kinetic constant defined by Equation (4), where $\eta$ was calculated according to Equations (6)-(8) for different effective diffusion coefficients $D_{\text {eff }}$. Based on the experimentally determined effectiveness factors and intrinsic kinetic constants, the effective diffusion coefficient can be deducted from Figure 8 and then the tortuosity can be calculated using Equation (10). The figure depicts points corresponding to each commercial catalyst. The calculation results for each commercially prepared catalyst are given in Table 4 and the following conclusion can be derived from them:

- The $\mathrm{K} / \mathrm{Co}_{4} \mathrm{MnAlO}_{\mathrm{x}}$-industry catalyst has the lowest $D_{k}$ due to its smallest pores and therefore the lowest overall diffusivity. It also has the second highest tortuosity, which means the second highest $\varepsilon_{\mathrm{p}} / q$ ratio (0.07) (the porosity of all catalysts is approximately the same). As a result, it has the lowest effective diffusion coefficient of all three commercial catalysts. Its activity could theoretically be improved via enlargement of pores and lowering their tortuosity, which would lead to an increase of the internal effectiveness factor.

- The $\mathrm{Cs} / \mathrm{Co}_{4} \mathrm{MnAlO}_{\mathrm{x}}$-industry has the most favorable morphology for transport because it has the highest effective diffusion coefficient due to the lowest tortuosity and pore size, which is comparable to $\mathrm{K} / \mathrm{Co}_{4} \mathrm{MnAlO}_{\mathrm{x}}$-industry. As a result, this catalyst had the highest value of $\eta(0.18)$ and there is still room to increase its value.

The $\mathrm{Cs} / \mathrm{Co}_{3} \mathrm{O}_{4}$-industry catalyst has the largest pores of all three catalysts, but at the same time the highest tortuosity and thus the least favourable $\varepsilon_{\mathrm{p}} / q$ ratio (0.02), resulting in the second highest effective diffusion coefficient. $D_{\text {eff }}$ could be further increased by lowering the tortuosity, which would lead to a significantly higher internal effectiveness factor. The diagram in Figure 8 can be used for $D_{\text {eff }}$ estimation also for other reactions with 1st order reaction kinetics, when the value of the intrinsic kinetic constant and internal effectiveness factor are known from experiments. The diagram is valid only for shaped catalysts in the form of pellets $5.1 \mathrm{~mm} \times 5.1 \mathrm{~mm}$ or for spheres with diameter of $5.1 \mathrm{~mm}$. 
To answer the third question of $\mathrm{N}_{2} \mathrm{O}$ conversion limits achievable on tablets by tuning their morphological characteristics, the conversions of $\mathrm{N}_{2} \mathrm{O}$ were calculated based on the 1st order intrinsic kinetic constant for different effective diffusion coefficients. The pseudo-homogeneous one-dimensional model of an ideal plug flow reactor in an isothermal regime, mentioned in our previous paper [12], was used for the calculation, where the effect of internal and external mass transport was described by the overall effectiveness factor $\Omega$. Considering that the resistance to mass transfer by internal diffusion is prevalent, the overall effectiveness factor was substituted by the internal effectiveness factor, which was incorporated into the 1st order kinetic equation $r=\eta k \mathrm{c}_{\mathrm{A}}$. This model disregards pressure drop.

In Table 4, the calculated $\mathrm{N}_{2} \mathrm{O}$ conversions for VHSV $=3000 \mathrm{~m}^{3} \cdot \mathrm{m}_{\text {bed }}{ }^{-3} \cdot \mathrm{h}^{-1}$ and catalyst tablets $5.1 \mathrm{~mm} \times 5.1 \mathrm{~mm}$ are compared with experimental $\mathrm{N}_{2} \mathrm{O}$ conversions determined at the same VHSV (Figure 2), and quite good agreement between the $\mathrm{X}_{\mathrm{N}_{2} \mathrm{O}}$ model and $\mathrm{X}_{\mathrm{N}_{2} \mathrm{O}}$ experiment was reached. The diagram showing the dependence of theoretically reachable $\mathrm{N}_{2} \mathrm{O}$ conversion on the 1st order kinetic constant in the kinetic regime is shown in Figure 9. The dependencies imply that the catalyst with a higher kinetic constant in the kinetic regime after tabletization can demonstrate lower $\mathrm{N}_{2} \mathrm{O}$ conversion than a sample which is less active in the kinetic regime, but has a more favorable tablet texture (pore size, porosity, and tortuosity). The figure depicts points corresponding to each commercial catalyst calculated according to reactor model. Their placement implies that the activity of the Cs $/ \mathrm{Co}_{4} \mathrm{MnAlO}_{4}$-industry catalyst ( $39 \% \mathrm{~N}_{2} \mathrm{O}$ conversion) cannot be further increased by much; since a $\mathrm{N}_{2} \mathrm{O}$ conversion of $50 \%$ corresponds to kinetic regime. The situation is similar for the $\mathrm{Cs} / \mathrm{Co}_{3} \mathrm{O}_{4}$-industry catalyst, which reaches $90 \%$ conversion under the given conditions, while the conversion corresponding to the kinetic regime is $100 \%$. On the other hand, there is a relatively large room for improvement of $\mathrm{N}_{2} \mathrm{O}$ conversion on the $\mathrm{K} / \mathrm{Co}_{4} \mathrm{MnAlO}_{x}$-industry sample ( $50 \%$ conversion) since a $\mathrm{N}_{2} \mathrm{O}$ conversion of $95 \%$ corresponds to the kinetic regime.

\section{Materials and Methods}

\subsection{Preparation of Catalysts at Laboratory Scale}

\subsection{1. $\mathrm{K} / \mathrm{Co}_{4} \mathrm{MnAlO}_{x}$ and $\mathrm{Cs} / \mathrm{Co}_{4} \mathrm{MnAlO}_{x}$}

The Co-Mn-Al layered double hydroxide (LDH) precursor with Co:Mn:Al molar ratio of 4:1:1 was prepared by co-precipitation of the corresponding nitrates in $\mathrm{Na}_{2} \mathrm{CO}_{3} / \mathrm{NaOH}$ solution at $25^{\circ} \mathrm{C}$ and $\mathrm{pH}$ 10. The product was washed and dried at $60^{\circ} \mathrm{C}$ and then calcined for $4 \mathrm{~h}$ at $500{ }^{\circ} \mathrm{C}$ in air. The prepared mixed oxide was then crushed and sieved to obtain a fraction with particle size of $0.160-0.315 \mathrm{~mm}$. The next step in preparation was impregnation by the pore filling method using aqueous solutions of $\mathrm{KNO}_{3}$ or $\mathrm{Cs}_{2} \mathrm{CO}_{3}$ to obtain a $\mathrm{K}$ content of $1.8 \mathrm{wt} \%$ and Cs content of $4 \mathrm{wt} \%$, respectively. The dried products were calcined for $4 \mathrm{~h}$ at $500{ }^{\circ} \mathrm{C}$ in air, sieved to obtain a fraction with particle size of $0.160-0.315 \mathrm{~mm}$ and marked as $\mathrm{K} / \mathrm{Co}_{4} \mathrm{MnAlO}_{x}$-lab and $\mathrm{Cs} / \mathrm{Co}_{4} \mathrm{MnAlO}_{x}$-lab.

\subsection{2. $\mathrm{Cs} / \mathrm{Co}_{3} \mathrm{O}_{4}$}

$\mathrm{Co}\left(\mathrm{NO}_{3}\right)_{2} \cdot 6 \mathrm{H}_{2} \mathrm{O}$ was added to an $\mathrm{NaOH}$ solution at room temperature while stirring. The concentration of the alkaline solution was chosen to maintain the required molar ratio of $\mathrm{OH}$ to $C o$ in the reaction mixture. The resulting suspension was maintained under stirring with air bubbling at room temperature for 5 minutes. Subsequently, the solid product was filtered, washed with distilled water, and dried at $30^{\circ} \mathrm{C}$. The dried products were calcined for $4 \mathrm{~h}$ at $500{ }^{\circ} \mathrm{C}$ in air and sieved to obtain a fraction with a particle size of $0.160-0.315 \mathrm{~mm}$. The next step in preparation was impregnation by the pore filling method using aqueous solutions of $\mathrm{Cs}_{2} \mathrm{CO}_{3}$ to obtain Cs content of $1 \mathrm{wt} \%$. The dried products were calcined for $4 \mathrm{~h}$ at $500{ }^{\circ} \mathrm{C}$ in air, sieved to obtain a fraction with particle size of $0.160-0.315 \mathrm{~mm}$ and marked as $\mathrm{Cs} / \mathrm{Co}_{3} \mathrm{O}_{4}-\mathrm{lab}$. 


\subsection{Preparation of Catalysts on Large Scale}

\subsection{1. $\mathrm{K} / \mathrm{Co}_{4} \mathrm{MnAlO}_{x}$ and $\mathrm{Cs} / \mathrm{Co}_{4} \mathrm{MnAlO}_{x}$}

The $\mathrm{Co}-\mathrm{Mn}-\mathrm{Al} \mathrm{LDH}$ with Co:Mn:Al molar ratio of 4:1:1 was used as a precursor of $\mathrm{Co}_{4} \mathrm{MnAlO}_{x}$ mixed oxide and was prepared by co-precipitation of the corresponding nitrates in an alkaline $\mathrm{Na}_{2} \mathrm{CO}_{3} / \mathrm{NaOH}$ solution at $25{ }^{\circ} \mathrm{C}$ and $\mathrm{pH} 10$. Concentrations of 40 and $106 \mathrm{~mol} / 1$ were used for $\mathrm{NaOH}$ and $\mathrm{Na}_{2} \mathrm{CO}_{3}$, respectively. The resulting suspension was filtered off, washed with water, dried at $60-105{ }^{\circ} \mathrm{C}$, and calcined for $4 \mathrm{~h}$ at $500{ }^{\circ} \mathrm{C}$ in air. The resulting product was milled, impregnated with $\mathrm{KNO}_{3}$ or $\mathrm{Cs}_{2} \mathrm{CO}_{3}$ to obtain $\mathrm{K}$ content of $1.8 \mathrm{wt} \%$ and Cs content of $4 \mathrm{wt} \%$, respectively, calcined $\left(4 \mathrm{~h}, 500{ }^{\circ} \mathrm{C}\right)$ and shaped into tablets $(5 \mathrm{~mm} \times 5 \mathrm{~mm})$. For better shaping, graphite was added. The catalyst was produced by ASTIN Catalysts and Chemicals, Ltd., Litvínov, Czech Republic and marked as $\mathrm{K} / \mathrm{Co}_{4} \mathrm{MnAlO}_{\mathrm{x}}$-industry and $\mathrm{Cs} / \mathrm{Co}_{4} \mathrm{MnAlO}_{\mathrm{x}}$-industry.

\subsection{2. $\mathrm{Cs} / \mathrm{Co}_{3} \mathrm{O}_{4}$-industry}

The $\mathrm{Co}(\mathrm{OH})_{2}-\beta$ was used as a precursor of $\mathrm{Co}_{3} \mathrm{O}_{4}$ and was prepared by co-precipitation of cobalt nitrates in an alkaline $\mathrm{NaOH}$ solution at $25{ }^{\circ} \mathrm{C}$. The resulting suspension was filtered off, washed with water, dried at $60{ }^{\circ} \mathrm{C}$ and calcined for $4 \mathrm{~h}$ at $500{ }^{\circ} \mathrm{C}$ in air. The resulting product was milled, impregnated with $\mathrm{Cs}_{2} \mathrm{CO}_{3}$ to obtain Cs content of $1 \mathrm{wt} \%$, dried, calcined $\left(4 \mathrm{~h}\right.$ at $\left.500{ }^{\circ} \mathrm{C}\right)$ and shaped into tablets $(5 \mathrm{~mm} \times 5 \mathrm{~mm}$ ). For better shaping, graphite was added. The catalyst was produced by ASTIN Catalysts and Chemicals, Ltd., Litvínov, Czech Republic and marked as $\mathrm{Cs} / \mathrm{Co}_{3} \mathrm{O}_{4}$.

\subsection{Characterization of Catalysts}

The chemical composition of samples was determined by atomic absorption spectrometry or atomic emission spectrometry using a SpectrAA880 instrument (Varian, Palo Alto, CA, USA) after dissolving the samples in hydrochloric acid.

Phase composition and microstructural properties were determined using the X-ray powder diffraction (XRD) technique. XRD patterns were obtained using a Rigaku SmartLab diffractometer (Rigaku, Tokio, Japan) with D/teX Ultra 250 detector. The source of X-ray irradiation was Co tube $\left(\mathrm{CoK} \alpha, \lambda_{1}=0.178892 \mathrm{~nm}, \lambda_{2}=0.179278 \mathrm{~nm}\right)$ operated at $40 \mathrm{kV}$ and $40 \mathrm{~mA}$. Incident slits were set up to irradiate a $10 \mathrm{~mm} \times 10 \mathrm{~mm}$ area of the sample (automatic divergence slits) constantly. The XRD patterns were collected in a $2 \theta$ range $5-90^{\circ}$ with a step size of $0.01^{\circ}$ and speed 0.5 deg.min ${ }^{-1}$. The samples were rotated $(30 \mathrm{rpm})$ during the measurement. Lattice parameters were refined using the LeBail method; the sizes of coherent domains were calculated using Scherrer's formula as an average of the five strongest diffractions with hkl symbols (220), (311), (400), (511), and (440) evaluated.

The surface areas of the catalysts were determined by $\mathrm{N}_{2}$ adsorption/desorption at $-196{ }^{\circ} \mathrm{C}$ using the ASAP 2010 instrument (Micromeritics, Ottawa, Ontario, Canada) and evaluated by the Brunauer-Emmett-Teller (BET) method. Prior to the measurement, both laboratory and commercially prepared samples were crushed to obtain a fraction $<0.16 \mathrm{~mm}$ and dried at $120^{\circ} \mathrm{C}$ for at least $12 \mathrm{~h}$.

In addition, textural properties of the commercially prepared catalysts were determined using the 3Flex physisorption set-up (Micromeritics, Ottawa, Ontario, Canada) and pieces of catalyst tablets were used for measurements. Before the physisorption measurement, the samples were dried at $120^{\circ} \mathrm{C}$ for $12 \mathrm{~h}$ in vacuum. The nitrogen adsorption-desorption isotherms were measured at $77 \mathrm{~K}$. The specific surface area, $S_{\mathrm{BET}}$, was calculated based on the BET method. The mesopore surface area, $S_{\text {meso }}$, and the micropore volume, $V_{\text {micro }}$, were evaluated by using the t-plot method, applying the Broekhoff-de-Boer standard isotherm. The total pore volume, $V_{\text {net }}$, was evaluated as the nitrogen volume adsorbed at maximum relative pressure $\left(p / p_{0}=0.99\right)$. The pore-size distribution was evaluated from adsorption data applying the Barrett-Joyner-Halenda $(\mathrm{BJH})$ method, assuming cylindrical pore geometry and using the Broekhoff-de-Boer standard isotherm with Faas correction.

The porous structure (mesopores and macropores) of commercial catalysts was characterized using a mercury porosimeter AutoPore III (Micromeritics, Ottawa, Ontario, Canada) working in the 
range of $0.1-400 \mathrm{MPa}$. Prior to the measurement, the samples were dried at $130^{\circ} \mathrm{C}$. Helium pycnometry (AccuPyc1330, Micrometrics, Ottawa, Ontario, Canada) was used to evaluate the sample's true density.

Temperature programmed reduction $\left(\mathrm{H}_{2}\right.$-TPR) measurements of the calcined samples $(0.025 \mathrm{~g})$ were performed using a system described in detail in [21], with a $\mathrm{H}_{2} / \mathrm{N}_{2}$ mixture $\left(10 \mathrm{~mol} \% \mathrm{H}_{2}\right)$, flow rate $50 \mathrm{ml} / \mathrm{min}$ and linear temperature increase of $20^{\circ} \mathrm{C} / \mathrm{min}$ up to $1000{ }^{\circ} \mathrm{C}$. The change in $\mathrm{H}_{2}$ concentration was evaluated using an Omnistar 300 mass spectrometer (Pfeiffer Vacuum, Asslar, Germany).

\subsection{Catalytic Tests on Laboratory Scale}

Catalytic experiments for laboratory prepared catalysts and crushed pellets with particle size $0.165-0.315 \mathrm{~mm}$ were performed in a reactor with an internal diameter of $5.5 \mathrm{~mm}$. A catalytic bed contained $0.1-0.3 \mathrm{~g}$ of the sample; the total flow rate was $100 \mathrm{ml} / \mathrm{min}\left(20^{\circ} \mathrm{C}, 101,325 \mathrm{~Pa}\right)$ containing $0.1 \mathrm{~mol} \% \mathrm{~N}_{2} \mathrm{O}, 5 \mathrm{~mol} \% \mathrm{O}_{2}$ and $2 \mathrm{~mol} \%$ water vapor in $\mathrm{N}_{2}$ leading to GHSV $=20,000-60,0001 \mathrm{~kg}^{-1} \mathrm{~h}^{-1}$ was applied to simulate the real waste gas from a nitric acid plant.

Experiments with commercially prepared pellets were performed in an integral reactor with an internal diameter of $50 \mathrm{~mm}$. The catalytic bed contained $10 \mathrm{ml}$ of the sample, the total flow rate was $500 \mathrm{ml} / \mathrm{min}\left(20^{\circ} \mathrm{C}, 101,325 \mathrm{~Pa}\right)$ containing $0.1 \mathrm{~mol} \% \mathrm{~N}_{2} \mathrm{O}, 5 \mathrm{~mol} \% \mathrm{O}_{2}$ and $2 \mathrm{~mol} \%$ water vapor in $\mathrm{N}_{2}$ to simulate the real waste gas from a nitric acid plant. VHSV $=3000 \mathrm{~m}^{3} \mathrm{~m}_{\text {bed }}{ }^{-3} \mathrm{~h}^{-1}$ was applied.

\subsection{Pilot Plant Catalytic Tests}

Pilot plant catalytic measurements of $\mathrm{N}_{2} \mathrm{O}$ decomposition were performed in a fixed bed stainless steel reactor $\left(0.31 \mathrm{~m}\right.$ internal diameter) in the temperature range of 350 to $450{ }^{\circ} \mathrm{C}$ and inlet pressure of $0.6 \mathrm{MPa}$. The reactor was connected to the bypassed tail gas from the nitric acid production plant downstream from the $\mathrm{SCR} \mathrm{NO} \mathrm{N}_{\mathrm{x}} / \mathrm{NH}_{3}$ catalyst. The catalyst tablets $\left(\mathrm{K} / \mathrm{Co}_{4} \mathrm{MnAlO}_{x}\right.$-industry: $69.1 \mathrm{~kg}$ weight, $62.5 \mathrm{~cm}$ bed height, $1334 \mathrm{~kg} \mathrm{~m}^{-3}$ bed density; $\mathrm{Cs} / \mathrm{Co}_{4} \mathrm{MnAlO}_{x}$-industry: $74.4 \mathrm{~kg}$ weight, $62.5 \mathrm{~cm}$ bed height, $1436 \mathrm{~kg} \mathrm{~m}^{-3}$ bed density; $\mathrm{Cs} / \mathrm{Co}_{3} \mathrm{O}_{4}$-industry: $75.9 \mathrm{~kg}$ weight, $60 \mathrm{~cm}$ bed height, $1527 \mathrm{~kg} \mathrm{~m}^{-3}$ bed density) were placed on a stainless steel grate sieve and a bed of ceramic spheres (diameter of $8 \mathrm{~mm}$ ) $5 \mathrm{~cm}$ in height. On the catalyst layer, again more ceramic spheres (height of $1 \mathrm{~cm}$ ), a sieve, and a last layer of ceramic spheres (height of $6.5 \mathrm{~cm}$ ) were placed. The feed to the reactor varied between 300 and $600 \mathrm{~kg} \mathrm{~h}^{-1}$ and contained typically $400-700 \mathrm{ppm}$ of $\mathrm{N}_{2} \mathrm{O}$ together with oxygen, water vapor, and a low concentration of $\mathrm{NO}, \mathrm{NO}_{2}$, and $\mathrm{NH}_{3}\left(0-70\right.$ ppm of $\mathrm{NO}_{\mathrm{x}}, 0-30 \mathrm{ppm}$ of $\mathrm{NH}_{3}$ ). The variable composition of gas mixture at the reactor inlet was due to the fact that the inlet gas was the real waste gas from the nitric acid plant downstream from the SCR $\mathrm{NO}_{\mathrm{x}} / \mathrm{NH}_{3}$ unit. Infrared and chemiluminescence online analyzers were used for analysis of the gas at the catalyst bed inlet and outlet: Sick $\left(\mathrm{N}_{2} \mathrm{O}\right)$, Horiba $\left(\mathrm{NO}, \mathrm{NO}_{2}\right)$, ABB modul Uras $26\left(\mathrm{~N}_{2} \mathrm{O}\right)$, and ABB Limas11 $\left(\mathrm{NO}, \mathrm{NO}_{2}\right.$, and $\mathrm{NH}_{3}$ ). The reactor was equipped with online monitoring of the concentrations of all measured gas components, the temperature in the catalyst bed, and the pressure drop.

\subsection{Determination of Internal Effectiveness Factor}

The internal effectiveness factor expresses the influence of the internal mass transport limitation on the overall rate of catalytic reaction and is defined by Equation (1).

$$
\begin{aligned}
& \eta=\frac{\text { Actual overall rate of reaction }}{\text { Rate of reaction that would result if entire interior }} \\
& \text { was exposed to external pellet surface conditions }
\end{aligned}
$$

Both the experimental determination and the theoretical calculation of $\eta$ were used. For the determination from experimental data, $\mathrm{N}_{2} \mathrm{O}$ conversions at the same reaction conditions had to be used for evaluation of both reaction rates in Equation (1). We assume that the rate of reaction on the catalyst in the form of grains is not affected by internal diffusion and can be used as the reaction 
rate at external pellet surface conditions. For the evaluation of the actual overall rate of reaction, $\mathrm{N}_{2} \mathrm{O}$ conversions over pellets were recalculated to the same GHSV which was used for the testing of grains (GHSV $=60,000 \mathrm{l} \mathrm{h}^{-1} \mathrm{~kg}^{-1}=0.00025 \mathrm{~m}^{3} \mathrm{~s}^{-1} \mathrm{~kg}^{-1}$ ) using 1st order kinetic equation and the material balance of an ideal plug flow reactor:

$$
X_{\mathrm{N}_{2} \mathrm{O}}=1-e^{\frac{-k}{\mathrm{GHSV}}}
$$

Kinetic constants over catalyst pellets and grains were calculated from $\mathrm{N}_{2} \mathrm{O}$ conversions according to Equations (3) and (4):

$$
\begin{gathered}
k=\frac{\ln \left(\frac{1}{1-X_{N_{2} O}}\right)}{\frac{w}{\dot{V}}} \\
k^{*}=k / \rho_{\mathcal{C}}
\end{gathered}
$$

where $k\left(\mathrm{~m}^{3} \mathrm{~s}^{-1} \mathrm{~kg}^{-1}\right)$ and $k^{*}\left(\mathrm{~s}^{-1}\right)$ are 1st order kinetic constants, $w(\mathrm{~kg})$ is the weight of catalyst, $\dot{V}\left(\mathrm{~m}^{3} \mathrm{~s}^{-1}\right)$ the total gas flow and $\rho_{c}\left(\mathrm{~kg} \mathrm{~m}^{-3}\right)$ is the bulk density of catalyst determined by $\mathrm{Hg}$ porosimetry. Then both reaction rates, defined as the amount of $\mathrm{N}_{2} \mathrm{O}$ converted per $\mathrm{kg}$ of catalysts per hour $\left(\mathrm{mol}_{\mathrm{N} 2 \mathrm{O}} \mathrm{kg}_{\mathrm{cat}}{ }^{-1} \mathrm{~h}^{-1}\right)$, were calculated ( $r_{\text {grain }}$ and $r_{\text {pellet}}$, respectively). The ratio of $r_{\text {grain }} / r_{\text {pellet }}$ provides the internal effectiveness factor of the pellets utilization.

$$
r=k \cdot c_{A 0} \cdot\left(1-X_{\mathrm{N}_{2} \mathrm{O}}\right)
$$

where $\mathrm{X}_{\mathrm{N}_{2} \mathrm{O}}$ is $\mathrm{N}_{2} \mathrm{O}$ conversion (-), $c_{\mathrm{A} 0}$ inlet $\mathrm{N}_{2} \mathrm{O}$ concentration $\left(\mathrm{mol} \mathrm{m}^{-3}\right)$.

For the theoretical estimation of the internal effectiveness factor $\eta$ for catalyst pellets, Equations (6)-(13) were used [22].

$$
\begin{gathered}
\eta=\frac{1}{\Phi_{g e n}} \cdot \tanh \Phi_{g e n} \quad \text { for } \Phi \text { gen }<4 \\
\eta=\frac{1}{\Phi_{g e n}} \quad \text { for } \Phi \text { gen }>4
\end{gathered}
$$

where the generalized Thiele modulus $\Phi_{\text {gen }}$ is defined:

$$
\Phi_{g e n}=\frac{V}{S} \cdot \sqrt{\frac{k \cdot \rho_{c}}{D_{e f f}}}
$$

where for cylinder pellet with equal diameter and height $\left(d_{\mathrm{p}}=h\right)$ :

$$
\frac{V}{S}=\frac{d_{p}}{6}
$$

The effective diffusion coefficient $D_{\text {eff }}$ is dependent on the morphology of porous catalyst:

$$
D_{e f f}=\frac{\varepsilon_{p}}{q} \bar{D}
$$

The $\varepsilon_{p} / q$ ratio between $0.05-0.1$ was published previously [23]. For the determination of the overall diffusivity of $\mathrm{N}_{2} \mathrm{O}$ in a multicomponent mixture $(\bar{D})$, the contributions of molecular $\left(D_{i / j}\right)$ and Knudsen $\left(D_{k, N_{2} O}\right)$ diffusivity was considered together with the stoichiometry of the reaction [12]:

$$
\frac{1}{\bar{D}}=\frac{1}{D_{k, N_{2} \mathrm{O}}}+\frac{x_{\mathrm{N}_{2} \mathrm{O}}+x_{\mathrm{N}_{2} \mathrm{O}}}{D_{\frac{\mathrm{N}_{2} \mathrm{O}}{\mathrm{N}_{2}}}}+\frac{0.5 \cdot x_{\mathrm{N}_{2} \mathrm{O}}+0.5 \cdot x_{\mathrm{N}_{2} \mathrm{O}}}{D_{\frac{\mathrm{N}_{2} \mathrm{O}}{\mathrm{O}_{2}}}}+\sum_{j=1}^{n} \frac{x_{\mathrm{N}_{2} \mathrm{O}}}{D_{\mathrm{N}_{2} \mathrm{O} / j}}
$$


where $j$ is a component of gas mixture. The Knudsen diffusivity $D_{k, N_{2} O}$ for pore with radius $r_{o}$ was determined [23] as:

$$
D_{k, \mathrm{~N}_{2} \mathrm{O}}=97 \cdot r_{0} \cdot \sqrt{\frac{T}{M_{\mathrm{N}_{2} \mathrm{O}}}}
$$

Binary diffusion coefficients $D_{i / j}$ were calculated from Equation (13) [24]:

$$
D_{i / j}=\frac{\frac{10^{-2} \cdot T^{\frac{7}{4}} \cdot\left(M_{j}^{-1}+M_{i}^{-1}\right)^{\frac{1}{2}}}{p}}{\left[\left(\sum v\right)_{i}^{\frac{1}{3}}+\left(\sum v\right)_{j}^{\frac{1}{3}}\right]^{2}}
$$

where $\left(\sum v\right)_{N_{2}}=17.9,\left(\sum v\right)_{N_{2} O}=35.9,\left(\sum v\right)_{\mathrm{O}_{2}}=16.6,\left(\sum v\right)_{\mathrm{H}_{2} \mathrm{O}}=12.7,\left(\sum v\right)_{\mathrm{He}}=$ 2.88, $\left(\sum v\right)_{N O}=11.17$.

\section{Conclusions}

Three cobalt containing mixed oxides modified with alkali metal promoters $\left(\mathrm{K}^{-} \mathrm{Co}_{4} \mathrm{MnAlO} \mathrm{O}_{x}\right.$, $\mathrm{Cs} / \mathrm{Co}_{4} \mathrm{MnAlO}_{x}$ and $\left.\mathrm{Cs} / \mathrm{Co}_{3} \mathrm{O}_{4}\right)$ were prepared commercially in the form of tablets. Their catalytic properties were tested for $\mathrm{N}_{2} \mathrm{O}$ catalytic decomposition in the laboratory and in a pilot plant reactor connected to the waste gas from a nitric acid production plant and compared to the laboratory prepared catalysts with the same chemical composition.

It was found that the different order of catalytic activities in the pilot-plant experiment compared to the laboratory prepared catalysts was caused by the different conditions of the pilot plant experiment, particularly by the presence of $\mathrm{NO}_{x}$ and $\mathrm{NH}_{3}$.

Comparison of $\mathrm{N}_{2} \mathrm{O}$ conversions of both laboratory and commercially prepared catalysts in the kinetic regime showed that $\mathrm{K} / \mathrm{Co}_{4} \mathrm{MnAlO}_{x}$ has active sites with nearly the same activity as the laboratory prepared sample and the kinetic constant of the tablets is lower mainly due to the inhibiting effect of internal diffusion. $\mathrm{N}_{2} \mathrm{O}$ conversion in such a case can be improved by increasing the internal effectiveness factor, i.e. by increasing $D_{\text {eff }}$, which can be achieved by increasing the pore size and also by increasing porosity and decreasing tortuosity.

Conversely, commercially prepared $\mathrm{Cs} / \mathrm{Co}_{4} \mathrm{MnAlO}_{x}$ and $\mathrm{Cs} / \mathrm{Co}_{3} \mathrm{O}_{4}$ catalysts possess active sites which are less active than those of laboratory prepared catalysts. $\mathrm{N}_{2} \mathrm{O}$ conversions on these tablets were lower partly due to the inhibiting effect of internal diffusion and also due to observed differences in reducibility, primary particle sizes, and probably also promoter normalized loading (atoms $/ \mathrm{nm}^{2}$ ) compared to laboratory prepared catalysts of the same chemical composition. $\mathrm{N}_{2} \mathrm{O}$ conversion on such tablets can be increased mainly by optimizing the preparation procedure and increasing the activity of the active sites (by increasing $k$ ).

The shown dependencies answer the question from the title of the paper: It is possible that a catalyst with a great performance in the kinetic regime can be less effective when prepared commercially in the form of tablets. The major reason for such changes in catalyst activity order after scale up are morphological characteristics (limiting mass transfer rates) and for that reason these can sometimes be even more important than the catalyst composition itself.

Author Contributions: Conceptualization, L.O.; methodology, L.O.; investigation, A.K.; data curation, A.K., L.M., K.P., and D.F.; writing—original draft preparation, L.O.; writing—review and editing, K.P. and L.M.

Funding: This research was funded by ERDF OP RDE project No. CZ.02.1.01/0.0/0.0/15_019/0000853 and by OP RDI project No. CZ.1.05/2.1.00/19.0389.

Acknowledgments: We thank Alexandr Martaus from the Institute of Environmental Technology VŠB-Technical University of Ostrava for the XRD measurements.

Conflicts of Interest: The authors declare no conflict of interest. 


\section{Symbols}

\begin{tabular}{|c|c|}
\hline$a$ & lattice parameter (nm) \\
\hline$c_{\mathrm{A}}$ & concentration of component $\mathrm{A}\left(\mathrm{N}_{2} \mathrm{O}\right)\left(\mathrm{mol} . \mathrm{m}^{-3}\right)$ \\
\hline$c_{\mathrm{A} 0}$ & initial concentration of component $\mathrm{A}\left(\mathrm{N}_{2} \mathrm{O}\right)\left(\mathrm{mol} \cdot \mathrm{m}^{-3}\right)$ \\
\hline $\bar{D}$ & overall diffusivity $\left(\mathrm{m}_{2} \cdot \mathrm{s}^{-1}\right)$ \\
\hline$D_{\text {eff }}$ & effective diffusion coefficient $\left(\mathrm{m}^{2} \cdot \mathrm{s}^{-1}\right)$ \\
\hline$D_{\mathrm{ij}}$ & binary diffusion coefficient of molecular diffusivity $\left(\mathrm{m}^{2} . \mathrm{s}^{-1}\right)$ \\
\hline$D_{k}$ & Knudsen diffusivity $\left(\mathrm{m}^{2} \cdot \mathrm{s}^{-1}\right)$ \\
\hline$d_{p}$ & equal catalyst particle diameter $(\mathrm{m})$ \\
\hline$k$ & kinetic constant, 1st order rate law $\left(\mathrm{m}^{3} \mathrm{~s}^{-1} \mathrm{~kg}^{-1}\right)$ \\
\hline$k^{*}$ & kinetic constant, 1st order rate law $\left(\mathrm{s}^{-1}\right)$ \\
\hline$L_{c}$ & size of coherent domains \\
\hline$M_{i}$ & molar weight of compound i (g.mol ${ }^{-1}$ ) \\
\hline$q$ & tortuosity (-) \\
\hline$r$ & reaction rate per unit weight of catalyst $\left(\mathrm{mol} \cdot \mathrm{kg}^{-1} \cdot \mathrm{h}^{-1}\right)$ \\
\hline$r_{0}$ & catalyst pore radius $(\mathrm{m})$ \\
\hline$S_{\mathrm{BET}}$ & specific surface area $\left(\mathrm{m}^{2} \mathrm{~g}^{-1}\right)$ \\
\hline$V$ & volume of the catalyst bed $\left(\mathrm{m}^{3}\right)$ \\
\hline$\dot{V}$ & total volumetric flow $\left(\mathrm{m}^{3} \mathrm{~s}^{-1}\right)$ \\
\hline$V_{\text {net }}$ & total pore volume $\left(\mathrm{cm}^{3}{ }_{\text {liq }} \mathrm{g}^{-1}\right)$ \\
\hline$v_{i}$ & molar volume of component $\mathrm{i}\left(\mathrm{m}^{3} \cdot \mathrm{kmol}^{-1}\right)$ \\
\hline$w$ & catalyst weight (g) \\
\hline$X_{A}$ & conversion of component $\mathrm{A}\left(\mathrm{N}_{2} \mathrm{O}\right)(-)$ \\
\hline$x_{\mathrm{N} 2 \mathrm{O}}$ & molar fraction of $\mathrm{N}_{2} \mathrm{O}$ entering the reactor $(-)$ \\
\hline \multicolumn{2}{|c|}{ Greek symbols: } \\
\hline$\varepsilon_{p}$ & porosity of catalyst particle (-) \\
\hline$\Phi_{\text {gen }}$ & generalized Thiele modul (-) \\
\hline$\eta$ & internal effectiveness factor (-) \\
\hline$\rho_{c}$ & bulk density of the catalyst $\left(\mathrm{kg} \cdot \mathrm{m}^{-3}\right)$ \\
\hline
\end{tabular}

\section{References}

1. Chromčáková, Ž.; Obalová, L.; Kustrowski, P.; Drozdek, M.; Karásková, K.; Jirátová, K.; Kovanda, F. Optimization of $\mathrm{Cs}$ content in $\mathrm{Co}-\mathrm{Mn}-\mathrm{Al}$ mixed oxide as catalyst for $\mathrm{N}_{2} \mathrm{O}$ decomposition. Res. Chem. Intermed. 2015, 41, 9319-9332. [CrossRef]

2. Obalová, L.; Karásková, K.; Jirátová, K.; Kovanda, F. Effect of potassium in calcined Co-Mn-Al layered double hydroxide on the catalytic decomposition of $\mathrm{N}_{2}$ O. Appl. Catal. B Environ. 2009, 90, 132-140. [CrossRef]

3. Lucie Obalová, S.M. Cesium doped $\mathrm{Co}_{3} \mathrm{O}_{4}$ spinel for $\mathrm{N}_{2} \mathrm{O}$ decomposition. In Proceedings of the 5th International Conference on Chemical Technology, Mikulov, Czech Republic, 10-12 April 2017.

4. Pacultová, K.; Karásková, K.; Kovanda, F.; Jirátová, K.; Šrámek, J.; Kustrowski, P.; Kotarba, A.; Chromčáková, Ž.; Kočí, K.; Obalová, L. K-Doped Co-Mn-Al Mixed Oxide Catalyst for $\mathrm{N}_{2} \mathrm{O}$ Abatement from Nitric Acid Plant Waste Gases: Pilot Plant Studies. Ind. Eng. Chem. Res. 2016, 55, 7076-7084. [CrossRef]

5. Pacultová, K.; Chromčáková, Ž.; Obalová, L. Cs doped cobalt based $\operatorname{deN}_{2} \mathrm{O}$ catalyst-Pilot plant results. Waste Forum 2017, 2, 54-63.

6. Inger, M.; Kowalik, P.; Saramok, M.; Wilk, M.; Stelmachowski, P.; Maniak, G.; Granger, P.; Kotarba, A.; Sojka, Z. Laboratory and pilot scale synthesis, characterization and reactivity of multicomponent cobalt spinel catalyst for low temperature removal of $\mathrm{N}_{2} \mathrm{O}$ from nitric acid plant tail gases. Catal. Today 2011, 176, 365-368. [CrossRef]

7. Inger, M.; Wilk, M.; Saramok, M.; Grzybek, G.; Grodzka, A.; Stelmachowski, P.; Makowski, W.; Kotarba, A.; Sojka, Z. Cobalt Spinel Catalyst for $\mathrm{N}_{2} \mathrm{O}$ Abatement in the Pilot Plant Operation-Long-Term Activity and Stability in Tail Gases. Ind. Eng. Chem. Res. 2014, 53, 10335-10342. [CrossRef]

8. Obalová, L.; Karásková, K.; Wach, A.; Kustrowski, P.; Mamulová-Kutláková, K.; Michalik, S.; Jirátová, K. Alkali metals as promoters in $\mathrm{Co}-\mathrm{Mn}-\mathrm{Al}$ mixed oxide for $\mathrm{N}_{2} \mathrm{O}$ decomposition. Appl. Catal. A Gen. 2013, 462-463, 227-235. 
9. Karásková, K.; Obalová, L.; Jirátová, K.; Kovanda, F. Effect of promoters in Co-Mn-Al mixed oxide catalyst on $\mathrm{N}_{2} \mathrm{O}$ decomposition. Chem. Eng. J. 2010, 160, 480-487. [CrossRef]

10. Yamada, K.; Pophal, C.; Segawa, K. Selective catalytic reduction of $\mathrm{N}_{2} \mathrm{O}$ by $\mathrm{C}_{3} \mathrm{H}_{6}$ over Fe-ZSM-5. Microporous Mesoporous Mater. 1998, 21, 549-555. [CrossRef]

11. Chmielarz, L.; Kuśtrowski, P.; Rafalska-Łasocha, A.; Dziembaj, R. Selective oxidation of ammonia to nitrogen on transition metal containing mixed metal oxides. Appl. Catal. B Environ. 2005, 58, 235-244. [CrossRef]

12. Obalová, L.; Jirátová, K.; Karásková, K.; Chromčáková, Ž. $\mathrm{N}_{2} \mathrm{O}$ catalytic decomposition - From laboratory experiment to industry reactor. Catal. Today 2012, 191, 116-120. [CrossRef]

13. Pasha, N.; Lingaiah, N.; Babu, N.S.; Reddy, P.S.S.; Prasad, P.S.S. Studies on cesium doped cobalt oxide catalysts for direct $\mathrm{N}_{2} \mathrm{O}$ decomposition in the presence of oxygen and steam. Catal. Commun. 2008, 10, 132-136. [CrossRef]

14. Stelmachowski, P.; Maniak, G.; Kotarba, A.; Sojka, Z. Strong electronic promotion of $\mathrm{Co}_{3} \mathrm{O}_{4}$ towards $\mathrm{N}_{2} \mathrm{O}$ decomposition by surface alkali dopants. Catal. Commun. 2009, 10, 1062-1065. [CrossRef]

15. Galejová, K.; Obalová, L.; Jiratova, K.; Pacultová, K.; Kovanda, F. $\mathrm{N}_{2} \mathrm{O}$ catalytic decomposition-Effect of pelleting pressure on activity of Co-Mn-Al mixed oxide catalysts. Chem. Pap. 2009, 63, 172-179. [CrossRef]

16. Gudyka, S.; Grzybek, G.; Gryboś, J.; Indyka, P.; Leszczyński, B.; Kotarba, A.; Sojka, Z. Enhancing the deN ${ }_{2} \mathrm{O}$ activity of the supported $\mathrm{Co}_{3} \mathrm{O}_{4} \mid \alpha-\mathrm{Al}_{2} \mathrm{O}_{3}$ catalyst by glycerol-assisted shape engineering of the active phase at the nanoscale. Appl. Catal. B Environ. 2017, 201,339-347. [CrossRef]

17. Klyushina, A.; Pacultová, K.; Karásková, K.; Jirátová, K.; Ritz, M.; Fridrichová, D.; Volodarskaja, A.; Obalová, L. Effect of preparation method on catalytic properties of Co-Mn-Al mixed oxides for $\mathrm{N}_{2} \mathrm{O}$ decomposition. J. Mol. Catal. A Chem. 2016, 425, 237-247. [CrossRef]

18. Kaczmarczyk, J.; Zasada, F.; Janas, J.; Indyka, P.; Piskorz, W.; Kotarba, A.; Sojka, Z. Thermodynamic Stability, Redox Properties, and Reactivity of $\mathrm{Mn}_{3} \mathrm{O}_{4}, \mathrm{Fe}_{3} \mathrm{O}_{4}$, and $\mathrm{Co}_{3} \mathrm{O}_{4}$ Model Catalysts for $\mathrm{N}_{2} \mathrm{O}$ Decomposition: Resolving the Origins of Steady Turnover. ACS Catal. 2016, 6, 1235-1246. [CrossRef]

19. Obalová, L.; Maniak, G.; Karásková, K.; Kovanda, F.; Kotarba, A. Electronic nature of potassium promotion effect in Co-Mn-Al mixed oxide on the catalytic decomposition of $\mathrm{N}_{2} \mathrm{O}$. Catal. Commun. 2011, 12, 1055-1058. [CrossRef]

20. Maniak, G.; Stelmachowski, P.; Zasada, F.; Piskorz, W.; Kotarba, A.; Sojka, Z. Guidelines for optimization of catalytic activity of $3 \mathrm{~d}$ transition metal oxide catalysts in $\mathrm{N}_{2} \mathrm{O}$ decomposition by potassium promotion. Catal. Today 2011, 176, 369-372. [CrossRef]

21. Jirátová, K.; Mikulová, J.; Klempa, J.; Grygar, T.; Bastl, Z.; Kovanda, F. Modification of Co-Mn-Al mixed oxide with potassium and its effect on deep oxidation of VOC. Appl. Catal. A Gen. 2009, 361, 106-116. [CrossRef]

22. Fogler, H.S. Elements of Chemical Reaction Engineering, 3rd ed.; Prentice Hall PTR: Upper Saddle River, NJ, USA, 1999.

23. Kaptejn, F.; Moulijn, J.A. Handbook of Heterogeneous Catalysis; Ertl, G., Knözinger, H., Weitkamp, J., Eds.; Wiley: Weinheim, Germany, 1996.

24. Fuller, E.N.; Schettler, P.D.; Giddings, J.C. New method for prediction of binary gas-phase diffusion coefficients. Ind. Eng. Chem. 1966, 58, 18-27. [CrossRef]

(C) 2019 by the authors. Licensee MDPI, Basel, Switzerland. This article is an open access article distributed under the terms and conditions of the Creative Commons Attribution (CC BY) license (http://creativecommons.org/licenses/by/4.0/). 